\title{
Petrology of Gameleira Potassic Lamprophyres, São Francisco Craton
}

\author{
JORGE PLÁ CID ${ }^{1}$, CRISTIANI S. CAMPOS ${ }^{2}$, LAURO V.S. NARDI ${ }^{3}$ and LUANA FLORISBAL ${ }^{4}$ \\ ${ }^{1}$ Departamento Nacional de Produção Mineral (DNPM), \\ Rua Alvaro Millen da Silveira, 151, Centro, 88020-180 Florianópolis, SC, Brasil \\ ${ }^{2}$ Departamento de Física, Universidade Federal de Santa Catarina, \\ Campus Universitário Reitor João David Ferreira Lima, Bairro Trindade, 88040-900 Florianópolis, SC, Brasil \\ ${ }^{3}$ Curso de Pós-Graduação em Geociências, Universidade Federal do Rio Grande do Sul, Instituto de Geociências, \\ Av. Bento Gonçalves, 9500, Campus da Agronomia, 91501-970 Porto Alegre, RS, Brasil \\ ${ }^{4}$ Universidade de São Paulo, Instituto de Geociências, Rua do Lago, 562, 05508-000 São Paulo, SP, Brasil
}

Manuscript received on May 16, 2011; accepted for publication on August 22, 2011

\begin{abstract}
Gameleira lamprophyres are dykes and mafic microgranular enclaves associated with the shoshonitic Gameleira monzonite. This association belongs to the Paleoproterozoic alkaline magmatism from Serrinha nucleus, northeast Brazil. The liquidus paragenesis is diopside, pargasite, apatite and mica. Reverse zoning was identified in the groundmass alkali feldspar and was related to the undercooling of lamprophyric magma during the emplacement, with high growth rate of pargasite/edenite inducing disequilibrium between feldspars and liquid. Chemical data indicate that the lamprophyres are basic rocks $\left(\mathrm{SiO}_{2}<48 \mathrm{wt} \%\right)$, with alkaline character $\left(\mathrm{Na}_{2} \mathrm{O}+\mathrm{K}_{2} \mathrm{O}>3 \mathrm{wt} \%\right)$ and potassic signature $\left(\mathrm{K}_{2} \mathrm{O} / \mathrm{Na}_{2} \mathrm{O} \approx 2\right)$. High contents of $\mathrm{MgO}$ and $\mathrm{Cr}$ are consistent with a signature of a primary liquid, and such concentrations, as well as $\mathrm{Al}, \mathrm{K}, \mathrm{P}, \mathrm{Ba}$, $\mathrm{Ni}$ - and light rare earth elements, are consistent with an olivine-free metasomatic mantle source enriched in amphibole, clinopyroxene and apatite. By contrast, the ultrapotassic lamprophyres from Morro do Afonso, contemporaneous alkaline ultrapotassic magmatism in Serrinha nucleus, were probably produced by melting of a clinopyroxene-phlogopite-apatite enriched-source. The identification of different mineral paragenesis in the source of potassic and ultrapotassic lamprophyres from Serrinha nucleus can contribute to the understanding of the mantle heterogeneities and tectonic evolution of this region.
\end{abstract}

Key words: potassic lamprophyres, Gameleira lamprophyres, São Francisco Craton, mantle metasomatism, petrology, mineralogy.

\section{INTRODUCTION}

Alkaline magmatism is frequent in within-plate settings (Whalen et al. 1987, Bonin 1996), associated to extensional processes, where it exhibits elevated concentrations of High Field Strength Elements

Correspondence to: Jorge Plá Cid

E-mail: jorge.pla@bol.com.br
(HFSE) in opposition to moderate and low amounts of Large Ion Lithophile Elements (LILE). This sort of alkaline anorogenic magmas support the usual concept of alkaline series and their evolution (Lameyre and Bowden 1982). Examples of withinplate magmatism in Bahia State, northeast Brazil, are the Paleoproterozoic Angico dos Dias carbonatites (Silva et al. 1988) and the alkaline and peralkaline 
granites from Campo Alegre de Lourdes (Plá Cid et al. 2001). In the Neoproterozoic, the best examples are the southern occurrences of undersaturated and saturated syenitic province (PASEBA; Rosa et al. 2002, 2005). During the last twenty years numerous occurrences of alkaline rocks in recent and ancient subduction-related settings have been studied (Thompson and Fowler 1986, Leat et al. 1988, Ringwood 1990, Nardi and Bonin 1991, Corriveau and Gorton 1993, Plá Cid et al. 2002, Sommer et al. 2005, and references therein). Compared to the within-plate, anorogenic and post-orogenic alkaline rocks, subduction-related alkaline magmas are depleted in HFSE and show strong enrichments in LILE and Light Rare Earth Elements (LREE), which has been interpreted by several authors, as related to a mantle source previously modified by dehydration-melting from a subducted-slab. In this sense, arc-related magmas are characteristically potassic, identified as belonging to the shoshonitic and potassic-ultrapotassic series, whereas the anorogenic within-plate magmas are dominantly sodic. This paper deals with potassic primary magmas, with arc-affinity, in the Paleoproterozoic of northeast Brazil and discusses mineralogical data obtained by Electron Microprobe in feldspars, amphibole and clinopyroxene.

\section{REGIONAL FRAMEWORK}

The São Francisco Craton (SFC) is a crustal segment of the South American Plataform stabilized in the Paleoproterozoic (1.8 Ga) and limited by Neoproterozoic $(0.6 \mathrm{Ga})$ reworked terrains. Internally, the SFC is segmented in three Archaean nuclei: Guanambi, Remanso and Serrinha from west to east, which are separated by NS-trending Paleoproterozoic fold belts formed by collisional events among these nuclei (Mascarenhas 1979). The studied area is located in the SN (Figure 1).

The main lithologies of the SN comprise: (i) an Archaean gneissic basement; (ii) Archa- ean calcalkaline TTG association; (iii) the Paleoproterozoic volcanic-sedimentary Rio Itapicuru Greenstone Belt (RIGB); (iv) Paleoproterozoic calc-alkaline rocks and TTG; (v) Paleoproterozoic alkaline magmatism. The Paleoproterozoic calcalkaline magmatism (2.06 - $2.16 \mathrm{Ga})$ shows Paleoproterozoic Sm-Nd T $\mathrm{DM}_{\mathrm{DM}}$ ages $(2.18-2.33 \mathrm{Ga})$, whereas the presence of Archaean TTG associations indicates an older subduction event. In this same way, the Paleoproterozoic $(2.08-2.10 \mathrm{Ga})$ alkaline magmatism produced Archaean Sm-Nd TDM ages $(2.58-2.96 \mathrm{Ga})$, and its subduction-related signature confirms the Archaean subductionrelated setting. For more isotopic data and detailed discussion, see Rios (2002).

The alkaline magmatism comprises shoshonitic batholiths (e.g. Itareru Massif; Figure 1) and ultrapotassic syenites and lamprophyres (e.g. Morro do Afonso Massif, Rios 2002). The studied area, called Gameleira, is located a few kilometers to the west of Morro do Afonso Massif (Figure 1). Preliminary data of Gameleira lamprophyres were presented by Plá Cid et al. (2007). The magmatism is represented by mafic dykes intrusive in monzonitic and quartz-monzonitic rocks, and mafic microgranular enclaves comingled with the monzonites. The host rocks are medium- to coarsegrained monzonites and consist of plagioclase and alkali feldspar phenocrysts, as well as amphibole, in a groundmass composed of the same minerals. Rare mica crystals were observed; titanite is the main accessory phase together with apatite. No metamorphic textures are present, and the internal crystal orientation is attributed to magma flow. The genetic correlation between the monzonites and the mafic rocks is possible, but this will not be discussed in this paper.

The main aim of this paper is to present geochemical and mineralogical data of the mafic magmatism associated with the Gameleira monzonite, which represents a primary magma derived from a metasomatic mantle-source. 


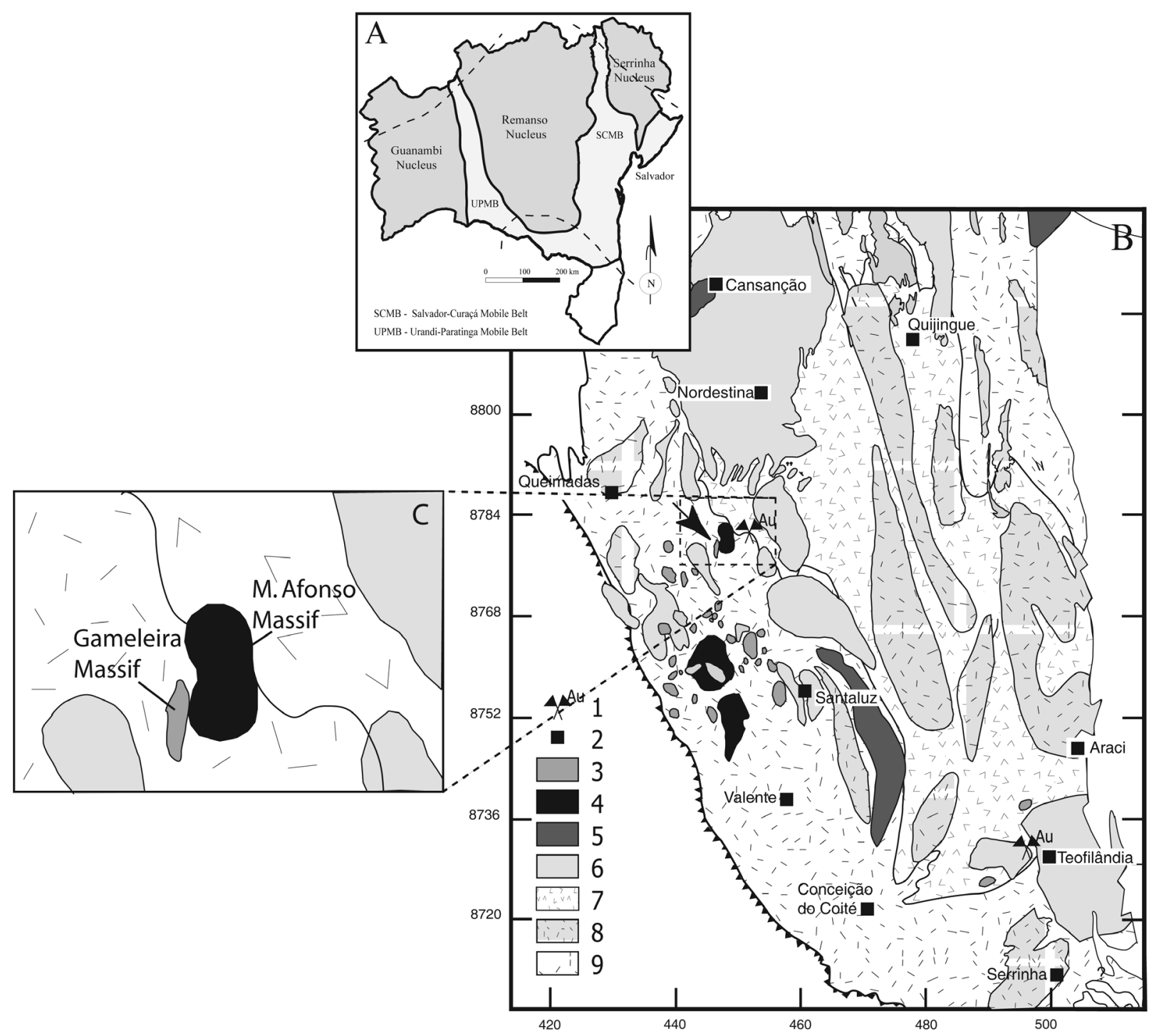

Figure 1. (A) Mascarenhas (1979) tectonic model to Paleoproterozoic in Bahia. (B) Simplified geological map of the southern part of the Serrinha nucleus with the proposal of Rios (2002) for the subdivision of granitic rocks. Legend: 1. Gold Mineralizations; 2. City; 3. Paleoproterozoic Potassic Granites; 4. Paleoproterozoic Ultrapotassic Syenites and Lamprophyres; 5. Paleoproterozoic Shoshonitic Monzonites; 6. Paleoproterozoic Calcalkaline Granites; 7. Rio Itapicuru Greenstone Belt; 8. Archaean TTG domes; 9. Archaean gneissic basement. (C) Detail of a portion of Figure 1B showing Gameleira and Morro do Afonso massifs.

Field AND PETROGRAPHic FEATURES

The alkaline mafic magmatism occurs as dykes and locally as microgranular enclaves, being contemporaneous to the Gameleira shoshonitic monzonite. Enclaves show elliptical or irregular shapes, are up to $10 \mathrm{~m}$ wide, show sinuous contacts with the monzonite host and internal flow structures. They are very fine-grained rocks aligned with the magmatic foliation of the monzonite, and frequently hybridized, as attested by feldspar xenocrysts of the host rock.

The better preserved examples of this magmatism are represented by dykes, which intrude 
the monzonite with straight and non-reactive contacts. These dykes are tabular intrusions, less than $0.5 \mathrm{~m}$ wide and more than $50 \mathrm{~m}$ long. These rocks are mafic, fine-grained, with black and dark green color.

\section{MinERALOGY}

The petrography of Gameleira dykes reveals amounts around 80 vol.\% of mafic minerals. Dykes are fine to very fine oriented inequigranular rocks, with euhedral amphibole crystals aligned by magmatic flow. Deep-green and brown amphiboles are the dominant mafic-phases, forming phenocrysts up to $0.1 \mathrm{~mm}$ long in a groundmass with an average size of $0.03 \mathrm{~mm}$. Euhedral apatite, mica and colorless clinopyroxene grains are included in the amphibole and are also oriented by the magmatic flow. The paragenesis formed by clinopyroxene-apatite-mica constitutes the near-liquidus assemblage. Subhedral apatite crystals are also associated with the latemagmatic interstitial minerals. Pyroxene and mica are limited to the near-liquidus stages. Subhedral yellowish allanite grains are included in amphibole and are therefore interpreted also as a nearliquidus mineral, pointing to a rare earth elements (REE) enriched liquid. Titanite occurs as anhedral crystals included in the amphibole, with sinuous contacts suggesting late-magmatic exsolution from the amphibole. Felsic minerals are interstitial, consisting of alkali feldspar and plagioclase. They usually form subhedral grains crystallizing interstitially to the mafic dominant minerals, during the latter magmatic stages. Some plagioclases and alkali-feldspars were observed included in amphibole large crystals, always near the border, showing that feldspar crystallized concomitantly with late crystallized amphibole. Plagioclase crystals are albite- and albite-Carlsbad twinned, whereas the alkali feldspar is frequently untwined and homogeneous, without perthite exsolution. The contacts between both are usually straight and well defined, and no reactions were observed. Textural features of the plagioclase and alkali feldspar suggest equilibrium during crystallization. Inclusions of iron oxides are also observed in the late-magmatic-crystallized felsic minerals, some amphibole rims and in the interstitial apatite, suggesting an increase in the $\mathrm{fO}_{2}$-conditions.

Based on mineral modal proportions, Gameleira lamprophyres can be classified as melanocratic diorites, as discussed previously by Plá Cid et al. (2007). However, the presence of amphibole, forming the near-liquidus phase, and feldspar restricted to the groundmass, are the typical characteristics that lead to classify them as lamprophyres (Rock 1987, Le Maitre et al. 1989). Close to Gameleira rocks $(<5 \mathrm{~km})$, vogesites and minettes associated with the Paleoproterozoic Morro do Afonso syenitic pluton (Rios 2002, Plá Cid et al. 2006). In the western part of the São Francisco Craton, a similar association was described by Paim et al. (2002) in the Paleoproterozoic Cara Suja Syenitic Pluton, associated mainly with ultrapotassic minette lamprophyres. The dominant mafic phase in the Gameleira dykes is amphibole, whereas alkali feldspar and plagioclase are restricted to the groundmass, indicating that the composition of these rocks range between vogesites and spessartites (Le Maitre et al. 1989).

The chemical analyses of the mineral phases from Gameleira lamprophyres were obtained using a JEOL Electron Microprobe, JXA 8600 model, at the Electron Microprobe Laboratory from São Paulo University (USP). Analytical conditions included a beam current of $10 \mathrm{nA}$, beam energy of $15 \mathrm{keV}$ and acquisition time of 20 s on the peak and 10 s on the background. Each element was standardized on either synthetic or natural minerals. The backscattered electron images (BSE) were acquired using a Scanning Electronic Microscope (SEM) at Electronic Microscopy Center of the Catholic Pontific University (PUC) from Rio Grande do Sul. 


\section{FELDSPARS}

BSE images were obtained using a SEM, and are shown in Figure 2. Such images reveal the non-reactive contacts between felsic minerals, a marked zoning in the alkali feldspar grains and incipient in the plagioclase, and the fine-grained texture of these lamprophyres.
Tables I and II display representative compositions of alkali feldspar and plagioclase crystals of Gameleira lamprophyres, respectively.

The alkali feldspar crystals are zoned and without exsolved plagioclase lamellae, as can be seen in the SEM images (Figure 2), and chemically may be classified as orthoclase or microcline (Figure 3). The interstitial character of the alkali

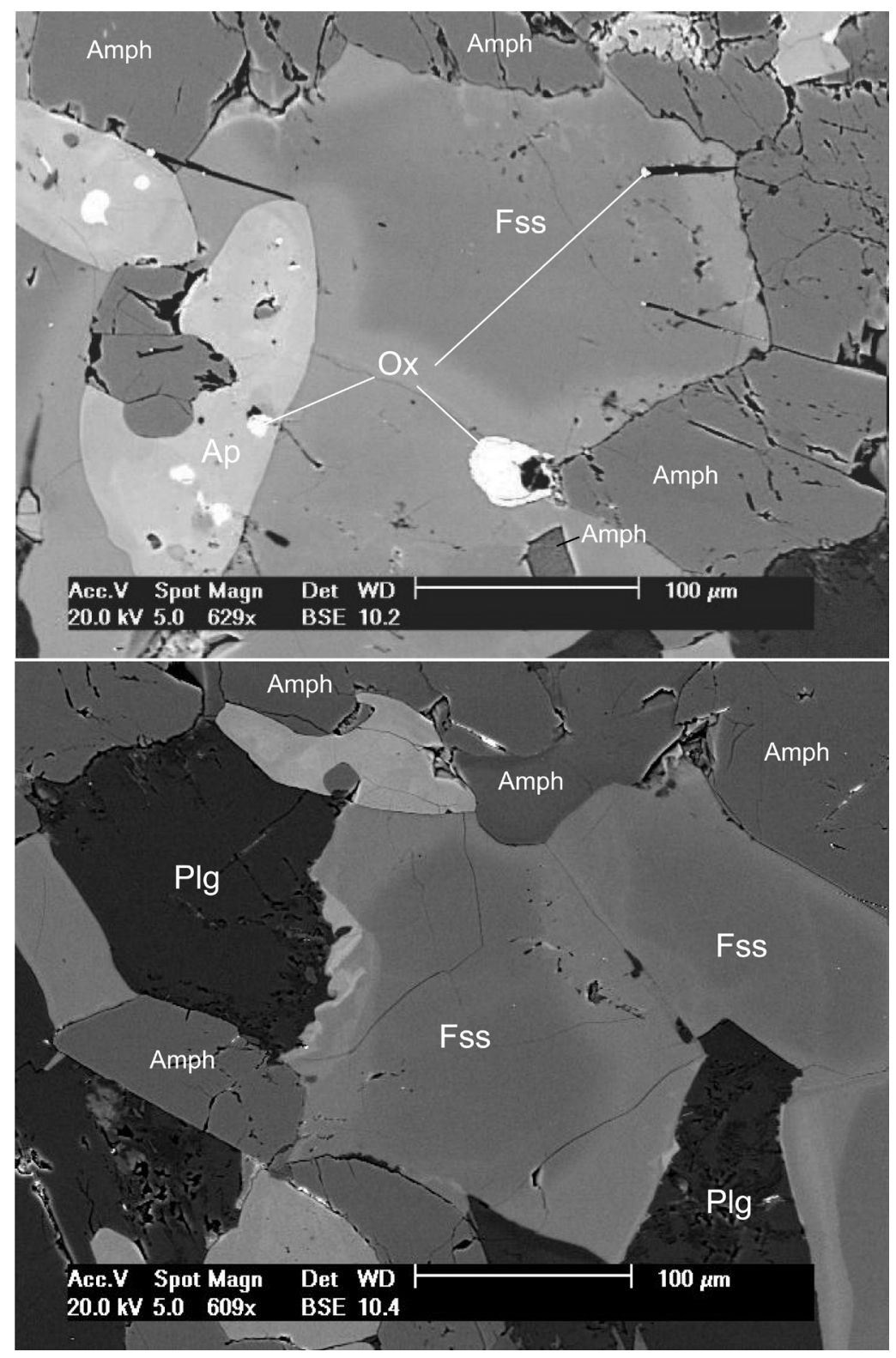

Figure 2. Scanning electron microscope images showing the textural relations in Gameleira lamprophyres. Legend: Fss - Alkali feldspar (solid solution), Plg - plagioclase, Amph amphibole, Ox - oxides, Ap - apatite. 
JORGE PLÁ CID, CRISTIANI S. CAMPOS, LAURO V.S. NARDI and LUANA FLORISBAL

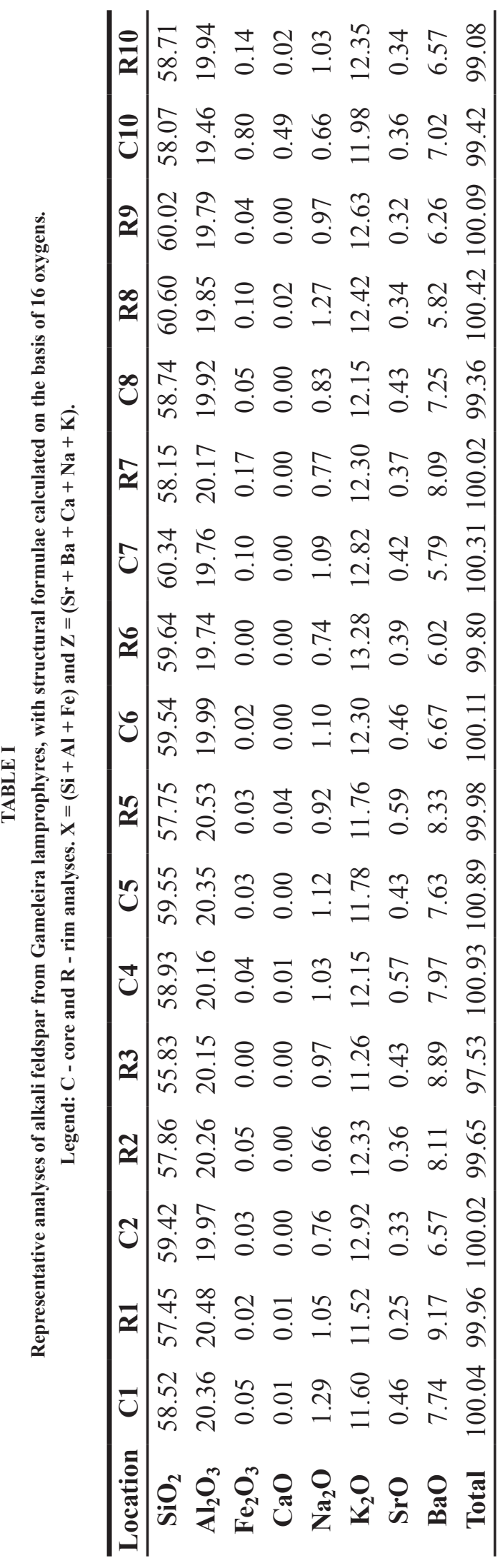

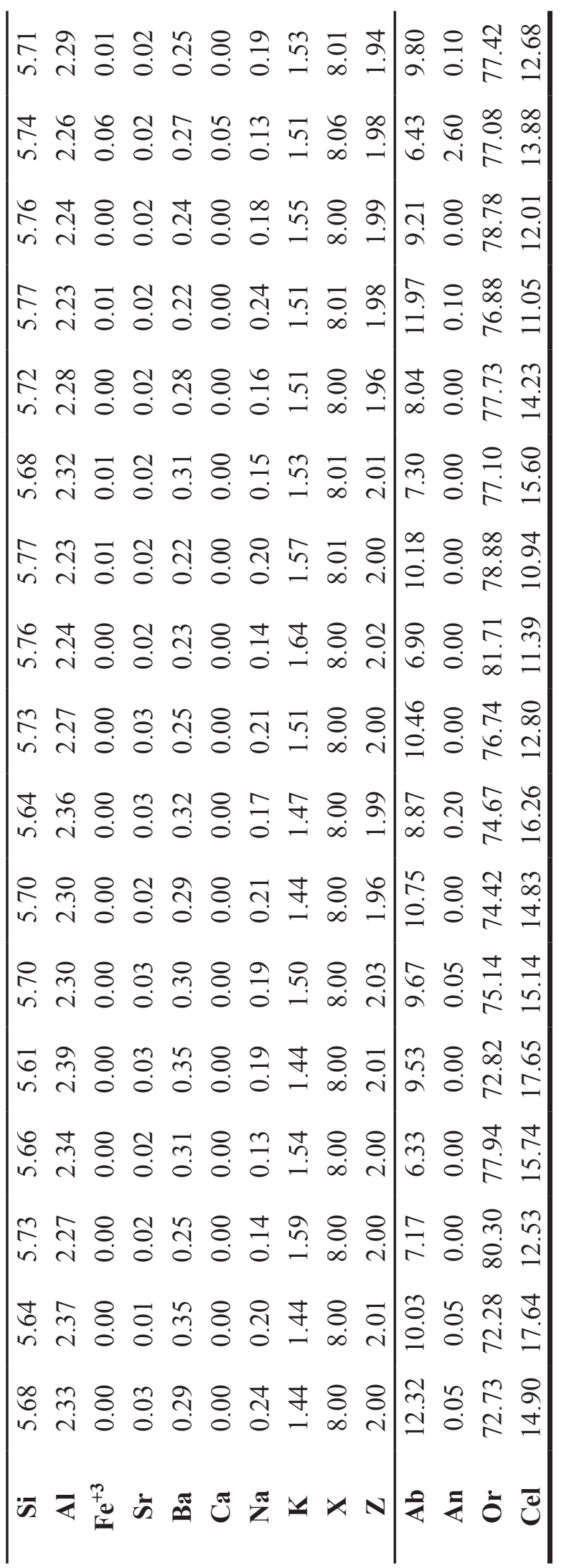




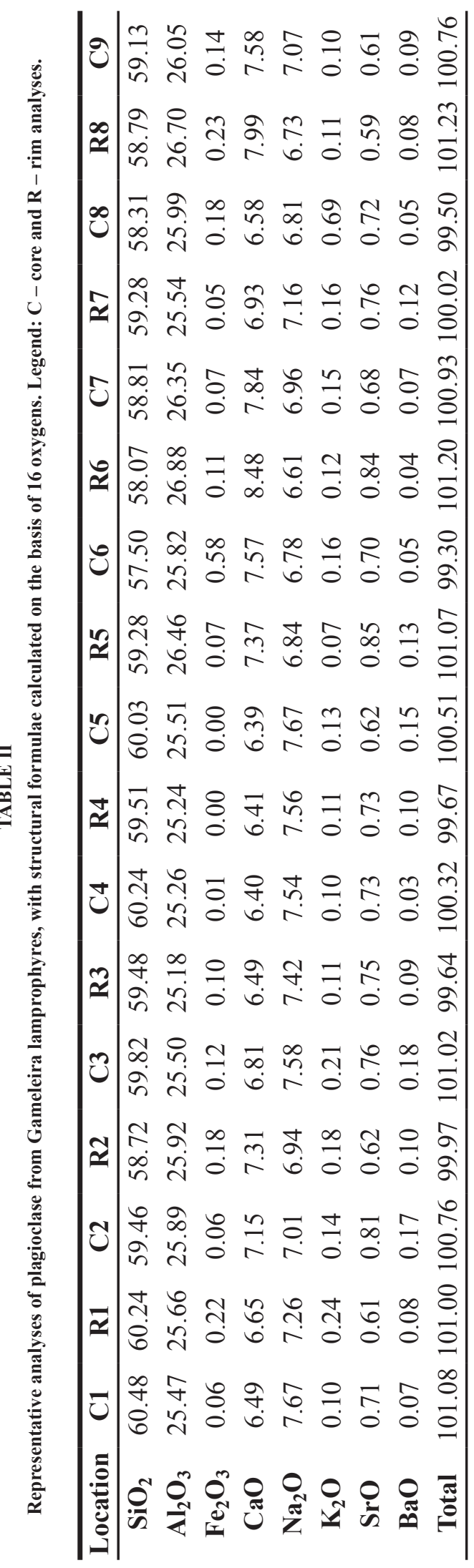

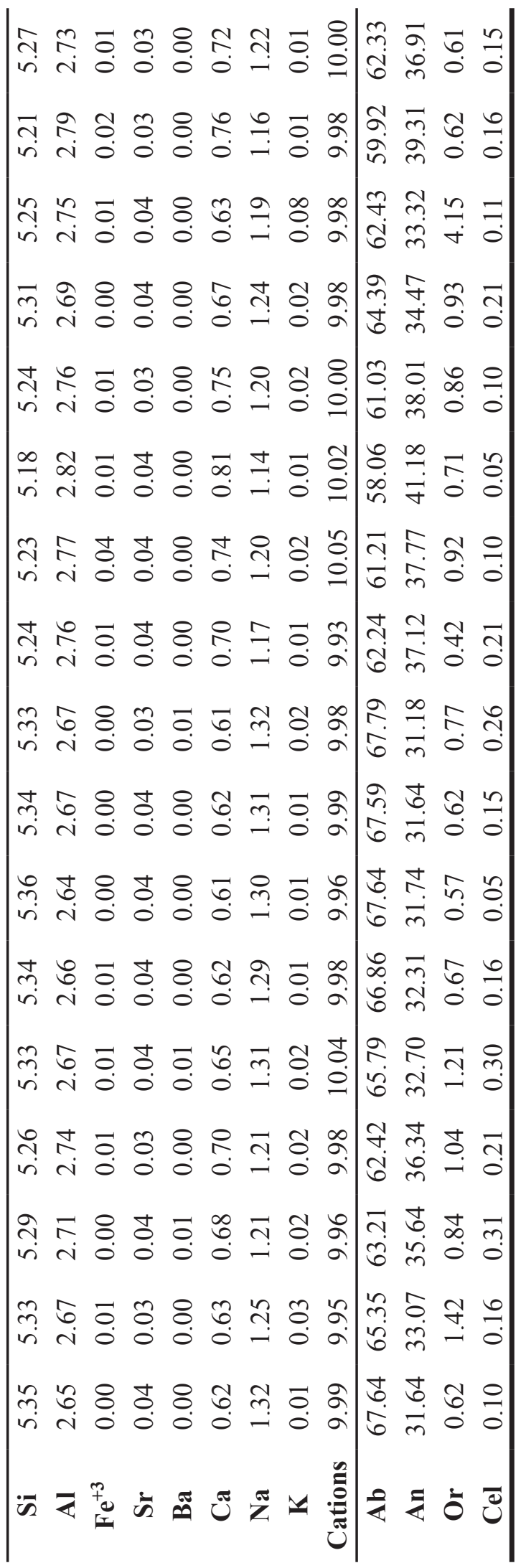

An Acad Bras Cienc (2012) 84 (2) 
feldspar, between larger crystals of amphibole, is also observed in the SEM images. Relatively large amounts of $\mathrm{Na}_{2} \mathrm{O}$ were determined $(\mathrm{Ab}$ $6.33 \mathrm{wt} \%$ to $14.65 \mathrm{wt} \%$ ), so that the absence of exsolved perthite may be a consequence of the fast crystallization of the lamprophyric magma, above the solvus temperature. High-temperature preserved composition and also points to monoclinic orthoclase instead of triclinic microcline.

Chemically, the alkali feldspar crystals are characterized by high $\mathrm{BaO}$ amounts (up to 9.16wt\%), with the celsian molecule reaching up to $17.65 \mathrm{wt} \%$ and belonging to the orthoclasecelsian solid-solution series. Significative anorthite contents are absent, as expected. $\mathrm{SrO}$ is between $0.19 \mathrm{wt} \%$ and $0.59 \mathrm{wt} \%$, which suggests a mineral/ melt partition coefficient higher than 1 .

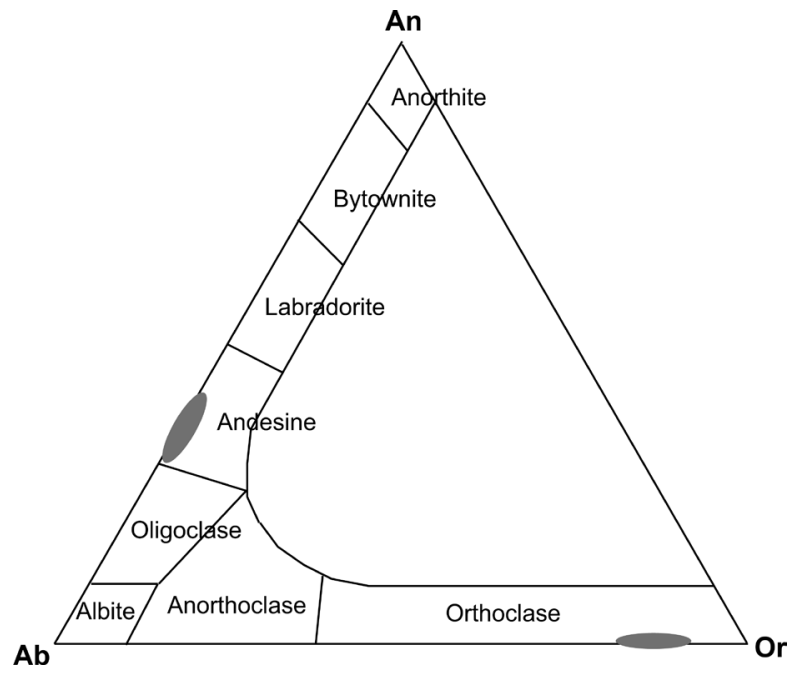

Figure 3. Anorthite (An) - Albite (Ab) - Orthoclase (Or) classificatory diagram of feldspars. Shadow areas correspond to the compositions of Gameleira feldspars.

As observed in Table I, the albite content is higher in the alkali feldspar cores. Only in two grains, normal zoning was observed: the albite enrichment occurs in the rims. The zoning was detected in the SEM images (Figure 2) as a narrow rim with sinuous contact. In the zoned grains, with analyses in the same crystal, the albite molecule is in the range of $A b_{6}$ and $A b_{12}$, with a higher decreasing observed in grain six $\left(\mathrm{Ab}_{10.46}\right.$ to $\left.\mathrm{Ab}_{6.90}\right)$. BSE images of Table II are in agreement with this chemical variation since clearer colors (rims) indicate higher average atomic number (richer in $\mathrm{K})$ and the darker cores a lower average atomic number (richer in $\mathrm{Na}$ ). Ba and $\mathrm{K}$ contents show a clear antipathetic behavior, and mutual substitution is highly probable. The increasing of $\mathrm{Al}$ in the borders of most alkali feldspar grains (Table I) associated with decreasing of Si produces charge unbalancing in the tetrahedral sites. The substitution involving larger ions, such as $\mathrm{K}^{+}$, is necessary to charge balancing of the structure. Substitution of $\mathrm{K}^{+}$and $\mathrm{Na}^{+}$by divalent ions of $\mathrm{Ba}^{++}$is suggested by the trends in Figure 4, showing the good trending of the coupled substitution including Si and ${ }^{\mathrm{IV}} \mathrm{Al}$.

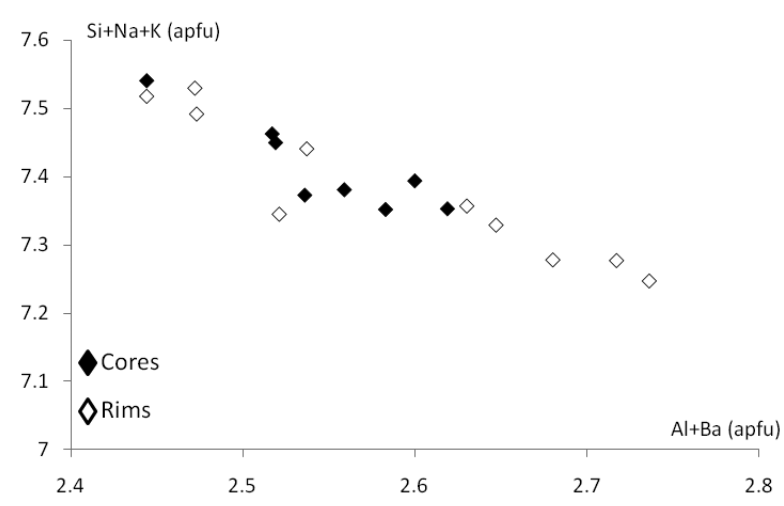

Figure 4. $\mathrm{Si}+\mathrm{Na}+\mathrm{K}$ vs. $\mathrm{Al}+\mathrm{Ba}$ diagram showing the substitutional scheme observed in alkali feldspars evolution of Gameleira lamprophyres.

The chemical analyses of plagioclase grains point to a dominant andesine composition $\left(\mathrm{An}_{30-}\right.$ 35) with some grains richer in calcium $\left(\mathrm{An}_{37-41}\right)$. The orthoclase amounts are very low (Or1.5-4.5). $\mathrm{Sr}$ contents are low and homogeneous (Table II). Celsian molecule occupies less than $0.3 \%$ of the plagioclase structure. In a general view, the plagioclase compositions are homogeneous, and the slight chemical variations suggest that crystallization of this mineral phase was quite fast. 


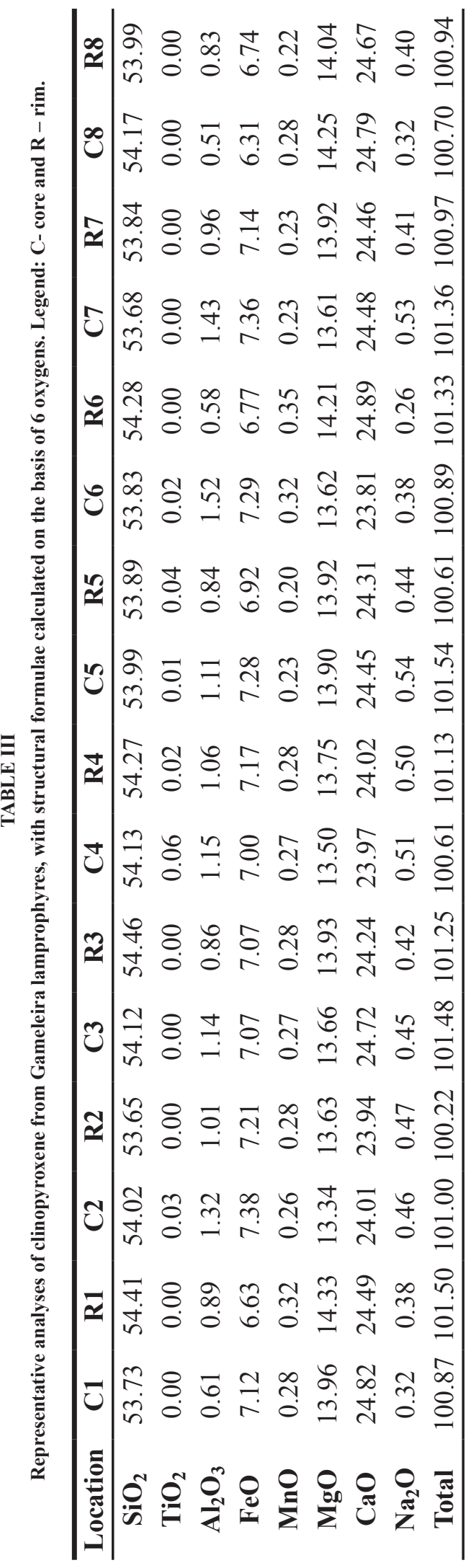

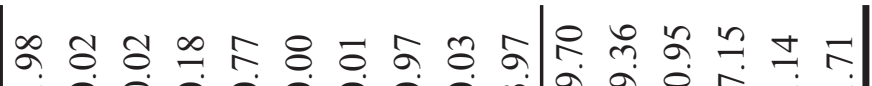

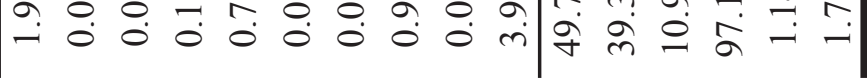

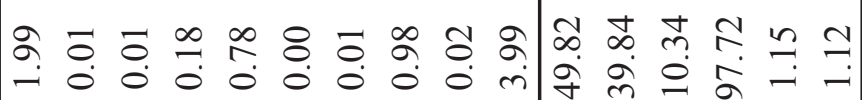
જ ลิ ๙ิ

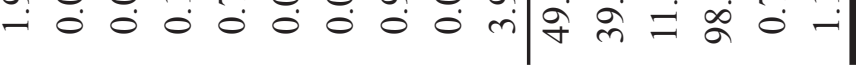

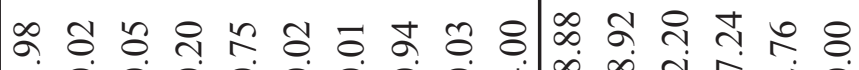

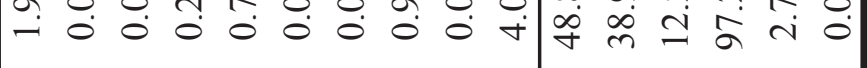
જે ลิ ล

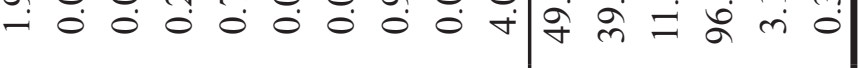

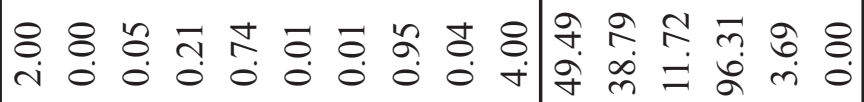

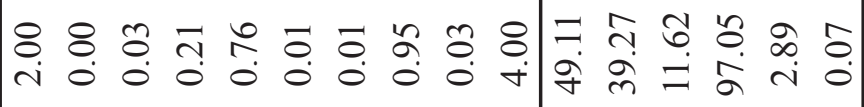
๙ ํํ

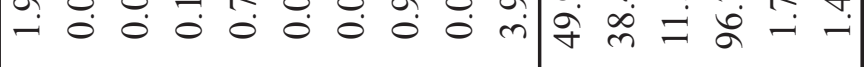

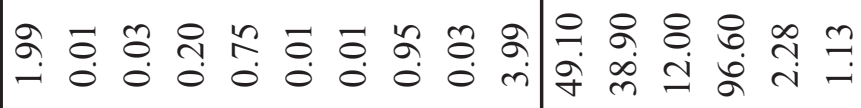
Әㅎ

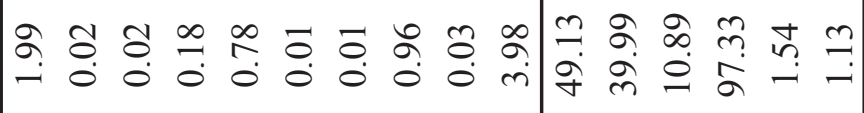
๙ 잉

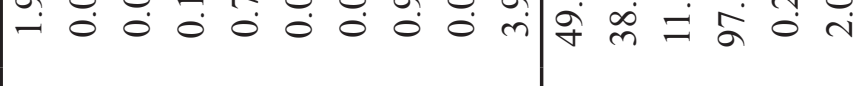

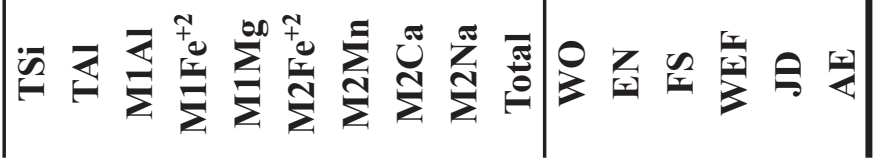


In six grains the albite molecule decreased from core to rims (Table II), although a variation around $2 \%$ that was not detected by SEM (Figure $2)$. The slight increase of An in some rims is balanced by the increase of $\mathrm{Al}^{+3}$ and the decrease of $\mathrm{Si}^{+4}$ in the tetrahedral site.

Then, some unusual behavior occurred during the crystallization of this magma to induce reverse zoning in the near-solidus felsic mineralogy, which was more evident in the alkali feldspar. Such feature is probably associated with the emplacement of the crystallizing magma in narrow (less than $40 \mathrm{~cm}$ wide) fractures along the host and cooler granite, inducing a fast temperature decrease.

\section{PYROXENE}

Chemical analyses from core to rim of clinopyroxene grains from Gameleira lamprophyres are given in Table III. Based on the modal classification of Morimoto (1988), these pyroxene grains are classified as diopside (Figure 5) and crystals are composed by high amounts of wollastonite $\left(\mathrm{Wo}_{48.9-49.9}\right)$ and enstatite (En) up to $39 \%$, and low ferrosilite (Fs) up to $12 \%$. For comparison, compositions of pyroxenes from Morro do Afonso (Plá Cid et al. 2006) and Cara Suja (Paim et al. 2002) lamprophyres, which have lower En contents reflecting lower $\mathrm{MgO} /\left(\mathrm{MgO}+\mathrm{FeO}_{\mathrm{t}}\right)$ ratio of these magmas, were included in Figure 3. Very low amounts of $\mathrm{Al}$ and $\mathrm{Na}$ (Table III) in the structure imply in very low contents of acmite and jadeite molecules (lower than 2\%). Diopside grains have homogeneous composition, with variations in terms of Wo-En-Fs molecules below 2\% (Table III), which suggests a short time of crystallization during the near-liquidus stages.

Neumann (1976) and Bonin and Giret (1985) demonstrated the correlation between the composition of magma in terms of some chemical elements and, their distribution in pyroxenes. $\mathrm{MgO} /$ $(\mathrm{MgO}+\mathrm{FeOt})$ ratio in the diopside of Gameleira

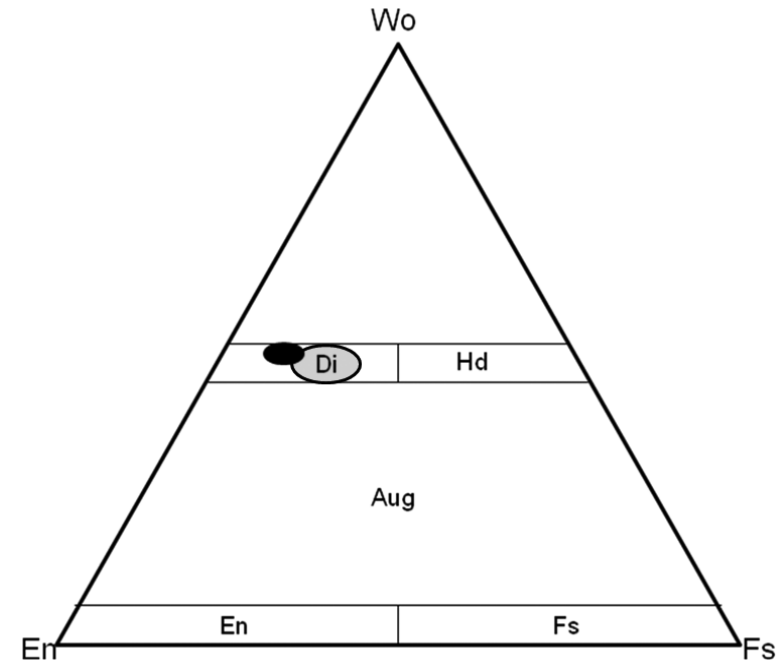

Figure 5 - Wollastonite (Wo) - Enstatite (En) - Ferroslite (Fs) triangular diagram from Morimoto (1988) for pyroxenes classification. Black filled ellipsoid corresponds to Gameleira clinopyroxenes and gray filled ellipsoid to Morro do Afonso (Plá Cid et al. 2006) and Cara Suja (Paim et al. 2002) lamprophyres.

lamprophyres is high and ranges between 0.64 and 0.69 , reflecting similar ratios in the magma, between 0.52 and 0.59 , considering all iron as ferrous. Similarly, $\mathrm{Na}_{2} \mathrm{O} /\left(\mathrm{CaO}+\mathrm{Na}_{2} \mathrm{O}\right)$ ratio is very low in diopside, between 0.012 and 0.021 , resulting in the very low ratio in the magma (0.072 to 0.089 ).

The variations of classical fractional crystallization indicators, as $\mathrm{Mg}, \mathrm{Ca}$ and $\mathrm{Na}$, in the pyroxene grains, show differences between centerborder lower than $0.5 \mathrm{wt} \%$ for $\mathrm{MgO}$ and $\mathrm{CaO}$, and $0.1 \mathrm{wt} \%$ for $\mathrm{Na}_{2} \mathrm{O}$. This is also a consequence of diopside size, normally less than $100 \mu \mathrm{m}$ and included in larger amphibole crystals.

AMPHIBOLES

Representative analyses of amphiboles in Gameleira lamprophyres are given in Table IV. Based on the amphibole nomenclature of Leake et al. (1997), the amphibole compositions from Gameleira lamprophyres are mainly edenite, and only a few compositions of pargasite occur in crystal's cores 
(Figure 6a). Three analyses are Mg-hornblende, as indicated by A-site $<0.5$ apfu (Figure 6b). Similar compositions of amphiboles from Morro do Afonso and Cara Suja lamprophyres are observed in Figure 6, with lower $\mathrm{Mg} /\left(\mathrm{Mg}+\mathrm{Fe}^{+2}\right)$ ratio. The amphibole from Gameleira dykes correspond to the lamprophyre magmatic amphibole field (Figure 7) as defined by (Rock 1991), similarly to amphiboles from Cara Suja (Paim et al. 2002) and Morro do Afonso lamprophyres (Plá Cid et al. 2006).
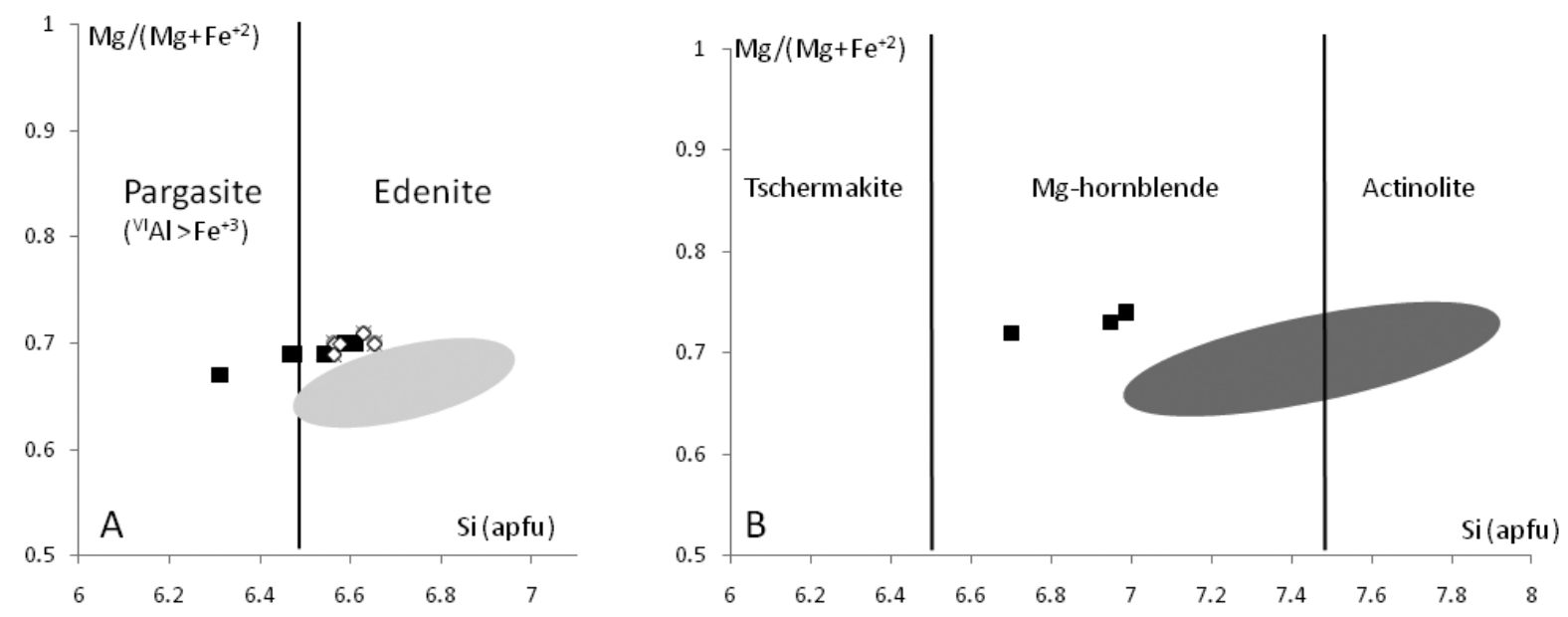

Figure 6. Amphibole diagram classification for calcic group (Leake et al. 1997) applied to the crystals from Gameleira lamprophyres. Legend: - Core analyses. $\diamond$ - Rim analyses. In Figure 06a gray filled ellipsoids correspond to Morro do Afonso (Figure 06a) and Cara Suja (Figure 06 b) amphiboles.

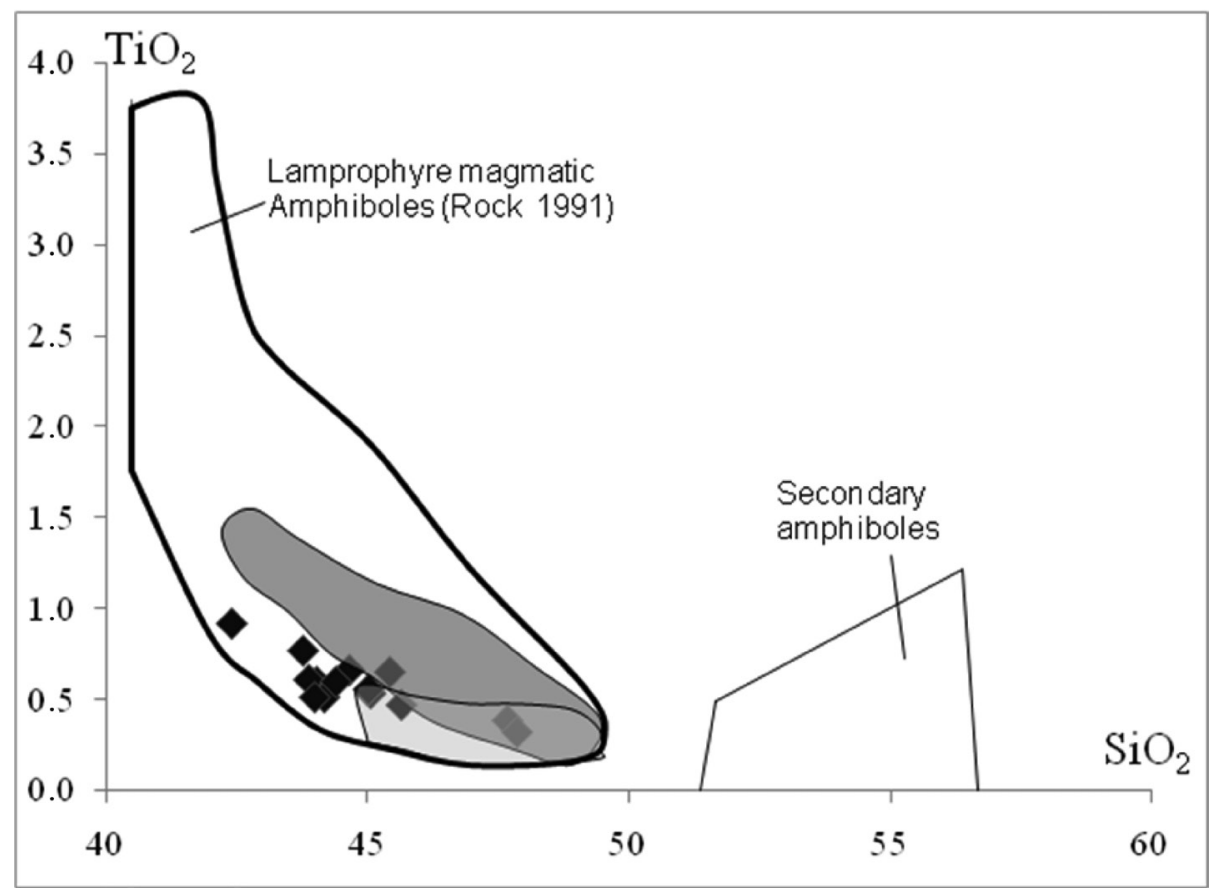

Figure 7. $\mathrm{TiO}_{2}$ (in $\mathrm{wt} \%$ ) vs $\mathrm{SiO}_{2}$ (in $\mathrm{wt} \%$ ) diagram showing the normal composition for primary and secondary amphiboles of lamprophyric rocks, according to Rock (1991). Filled lozenges correspond to Gameleira amphiboles, clearer shadow area to Cara Suja amphiboles (Paim et al. 2002) and darker shadow area to Morro do Afonso amphiboles (Plá Cid et al. 2006). 


$$
\text { 竞 }
$$

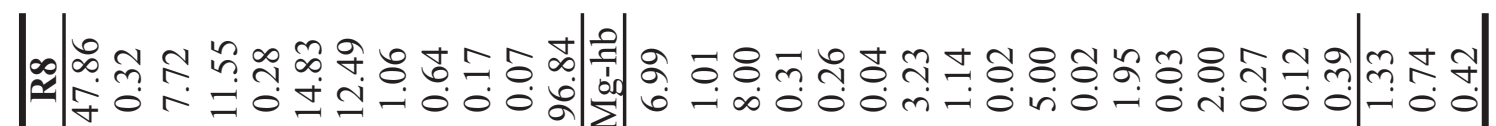

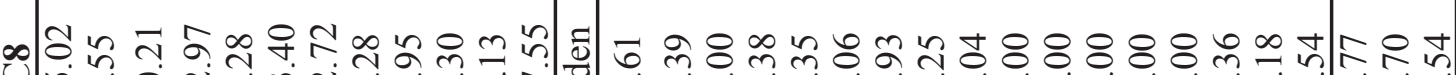
サं。

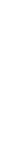

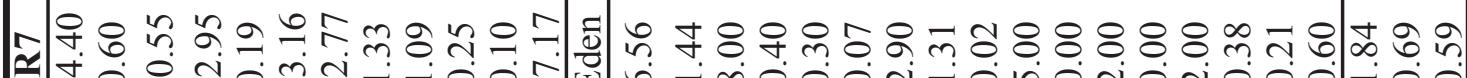

$\approx \mid \begin{aligned} & \dot{0} \\ & 0\end{aligned}$

능 ㅇํㅇำ

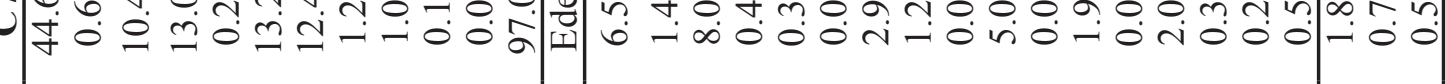

ำ

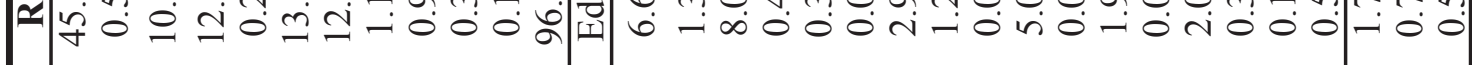

-

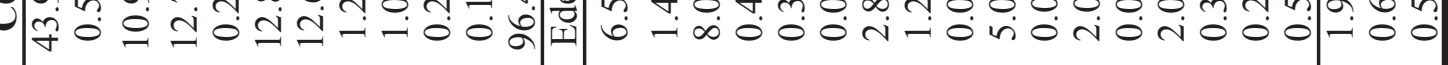

๓ $\approx \mid \forall 0$

nํำ

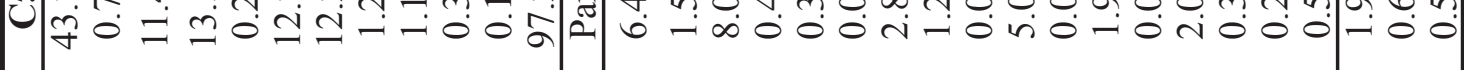

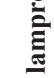

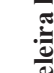

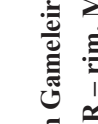

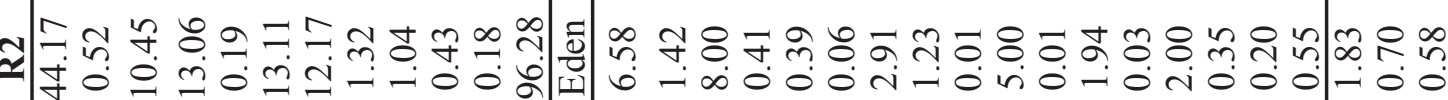

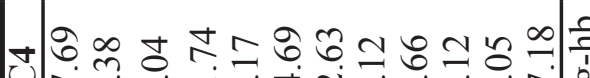

응ำ

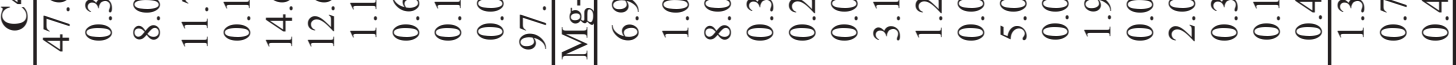

m

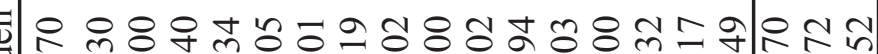

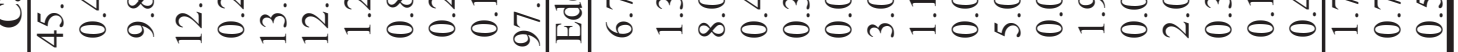

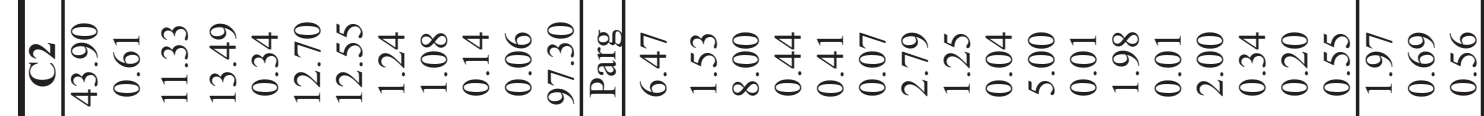

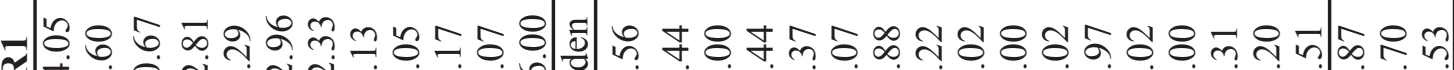

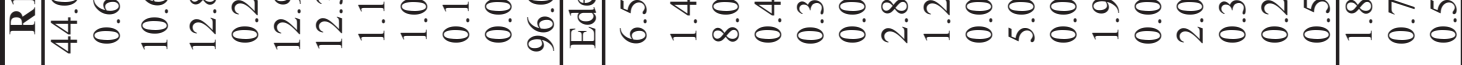

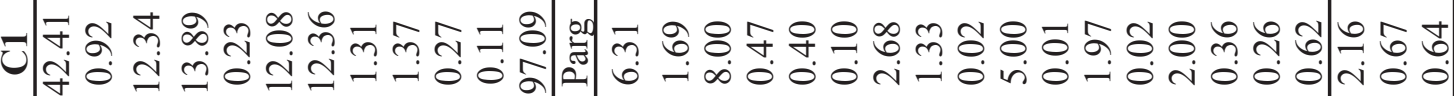
U

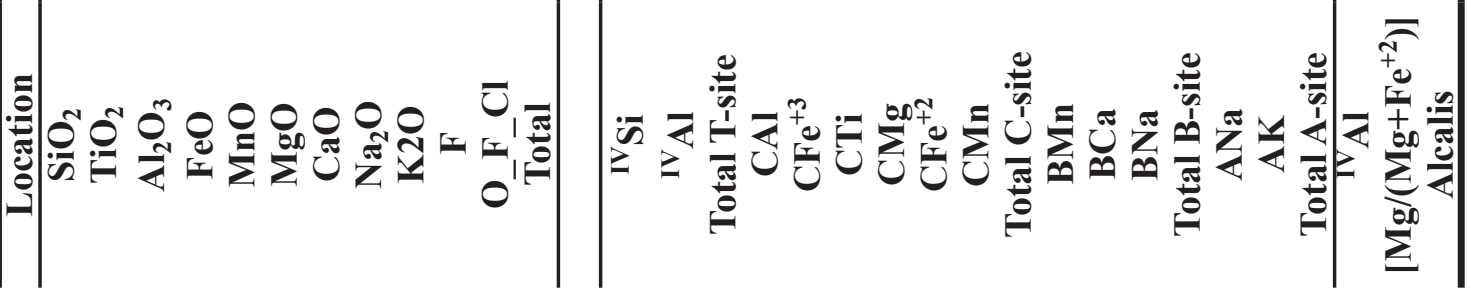


The trend from pargasite core to edenite rims (Figure 6a) is characterized by progressive decreases in ${ }^{\mathrm{T}} \mathrm{Al}$, with the higher contents in pargasite cores (1.96 to 2.1apfu) and the lowest in the Mg-hornblende crystals (1.33 to 1.38apfu). The three Mg-hornblende grains have the lower amounts of $\mathrm{Fe}^{+3}$ (Table IV) and result of the simultaneous crystallization of iron oxides during the later magmatic-stages under higher $\mathrm{fO}_{2^{-}}$ conditions. The same feature was reported in the Paleoproterozoic Cara Suja and Morro do Afonso potassic/ultrapotassic lamprophyres (Paim et al.
2002, Plá Cid et al. 2006). Ti contents also decrease with crystallization (Table IV) and reflect the latemagmatic or subsolidus crystallization of titanite.

Alkali $(\mathrm{Na}+\mathrm{K})$ elements are relatively enriched in the pargasite, as evidenced by the filling in A-site ( $55 \%$ to $62 \%$ ), whereas it ranges from $50 \%$ to $58 \%$ in edenite and from $39 \%$ to $42 \%$ in $\mathrm{Mg}$-hornblende. The decrease of alkali element contents with amphibole crystallization is illustrated in figure 8 . A similar behavior was described in the Cara Suja and Morro do Afonso lamprophyres (Paim et al. 2002, Plá Cid et al. 2006).

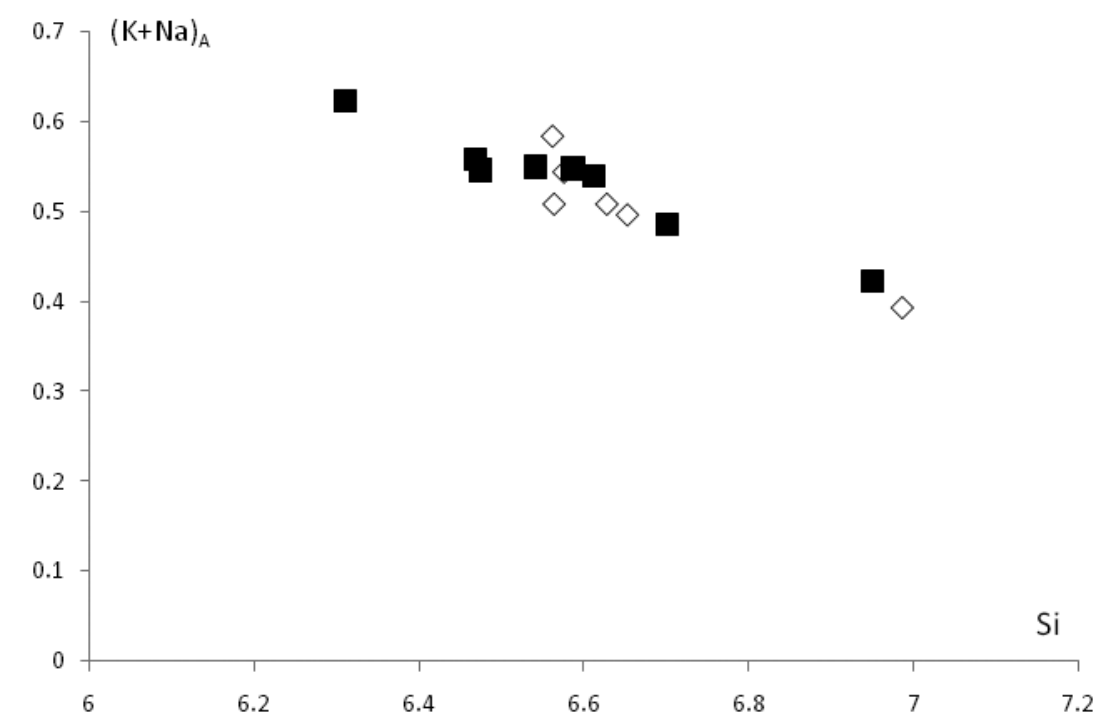

Figure 8. $\mathrm{K}+\mathrm{Na}$ (apfu) vs $\mathrm{Si}$ (apfu) diagram for the amphiboles of Gameleira lamprophyres showing the constant decrease in alkalies with evolution. Legend: - Core analyses. $\diamond$ - Rim analyses.

\section{WHOLE ROCK GEOCHEMISTRY}

The chemical data listed in table V were accomplished in the Acme Analytical Laboratories Ltd. (Canada). Major elements were determined by ICP-ES. Trace and rare- earth elements by ICPMS. All determinations are above the detection limits and the calculated errors are below 5\%. For comparison, in this table are also shown the ultrapotassic lamprophyres from Morro do Afonso Massif (Rios 2002).
Gameleira lamprophyres have low $\mathrm{SiO}_{2}$ contents (44 - $48 \mathrm{wt} \%)$, total alkalis close to $3 \mathrm{wt} \%$ and $\mathrm{K}_{2} \mathrm{O} / \mathrm{Na}_{2} \mathrm{O}$ ratio around 2 . In the TAS diagram (Figure 9) these lamprophyres plot in the silica-saturated alkaline field. The relation between $\mathrm{K}_{2} \mathrm{O}$ and $\mathrm{Na}_{2} \mathrm{O}$, according to the proposition of Le Maitre et al. (1989), points to a primary alkaline magma with a dominant potassic character. The low $\mathrm{Al}_{2} \mathrm{O}_{3}$ contents $(<10 \mathrm{wt} \%)$ are unusual in the shoshonitic series as described by Morrison (1980) and, in the same way, $\mathrm{K}_{2} \mathrm{O}$ concentrations below 
TABLE V

Representative chemical analysis from Gameleira and Morro do Afonso lamprophyres (Plá Cid et al. 2007, Rios 2002, respectively), and host Gameleira monzonites. Legend: n.d. - not determined.

\begin{tabular}{|c|c|c|c|c|c|c|c|c|c|}
\hline Sample & $11 / 22 a$ & $11 / 22 b$ & $11 / 22 \mathrm{c}$ & $9 / 22 \mathrm{c} 1$ & $10 / 22 \mathrm{c}$ & $10 / 21 \mathrm{e}$ & $11 / 21 \mathrm{c}$ & 952 & 953 \\
\hline & Gameleira & Gameleira & Gameleira & Gameleira & Gameleira & $\begin{array}{c}\text { Host } \\
\text { Monzonite }\end{array}$ & $\begin{array}{c}\text { Host } \\
\text { Monzonite }\end{array}$ & $\begin{array}{l}\text { Morro } \\
\text { Afonso }\end{array}$ & $\begin{array}{l}\text { Morro } \\
\text { Afonso }\end{array}$ \\
\hline $\mathrm{SiO}_{2}$ & 46.62 & 47.96 & 44.93 & 46.94 & 46.48 & 59.29 & 58.95 & 50.90 & 52.00 \\
\hline $\mathrm{TiO}_{2}$ & 1.44 & 1.45 & 1.51 & 1.41 & 1.44 & 0.71 & 0.78 & 1.10 & 1.00 \\
\hline $\mathrm{Al}_{2} \mathrm{O}_{3}$ & 9.40 & 9.42 & 9.72 & 10.35 & 9.68 & 15.3 & 15.27 & 10.60 & 11.20 \\
\hline $\mathrm{Fe}_{2} \mathrm{O}_{3}$ & 11.07 & 10.03 & 11.59 & 10.86 & 10.99 & 5.95 & 6.87 & 3.60 & 4.00 \\
\hline $\mathrm{FeO}$ & n.d. & n.d. & n.d. & n.d. & n.d. & n.d. & n.d. & 5.70 & 4.70 \\
\hline MnO & 0.18 & 0.20 & 0.18 & 0.20 & 0.21 & 0.08 & 0.11 & 0.19 & 0.18 \\
\hline MgO & 11.22 & 12.02 & 11.42 & 10.90 & 12.09 & 3.69 & 3.97 & 7.70 & 6.80 \\
\hline $\mathrm{CaO}$ & 12.32 & 12.19 & 13.74 & 12.43 & 12.72 & 5.63 & 5.64 & 10.30 & 9.50 \\
\hline $\mathrm{Na}_{2} \mathrm{O}$ & 1.03 & 1.13 & 1.07 & 1.21 & 1.18 & 4.18 & 4.24 & 1.10 & 1.10 \\
\hline $\mathrm{K}_{2} \mathrm{O}$ & 2.16 & 2.20 & 1.75 & 1.97 & 1.98 & 2.93 & 2.61 & 4.10 & 4.90 \\
\hline $\mathrm{P}_{2} \mathrm{O}_{5}$ & 1.83 & 1.40 & 1.97 & 1.62 & 1.59 & 0.49 & 0.53 & 1.50 & 1.50 \\
\hline LOI & 2.00 & 1.20 & 1.10 & n.d. & n.d. & 0.6 & 0.5 & n.d. & n.d. \\
\hline Total & 99.27 & 99.20 & 98.98 & 97.89 & 98.36 & 98.85 & 99.47 & 96.79 & 96.88 \\
\hline $\mathbf{B a}$ & 3497 & 4281 & 5399 & 3745 & 4073 & n.d. & 1588 & 5394 & 6105 \\
\hline $\mathbf{R b}$ & 62 & 135 & 76 & n.d. & 132 & n.d. & 201 & 89 & 115 \\
\hline $\mathbf{S r}$ & 800 & 633 & 894 & 530 & 633 & n.d. & 1074 & 1838 & 2112 \\
\hline Cs & 1.7 & 11.5 & 3.1 & n.d. & 10.4 & n.d. & 35.5 & 5 & 5 \\
\hline $\mathbf{Y}$ & 44.5 & 56.7 & 59.3 & 51 & 50.5 & n.d. & 33.4 & 40 & 41 \\
\hline $\mathbf{Z r}$ & 410 & 340 & 524 & 238 & 419 & n.d. & 266 & 352 & 333 \\
\hline $\mathbf{N b}$ & 22.5 & 13.6 & 19.9 & 19.6 & 19.9 & n.d. & 10 & 11 & 16 \\
\hline Th & 66.3 & 52 & 77 & n.d. & 62.8 & n.d. & 12.9 & 33 & 24 \\
\hline $\mathbf{P b}$ & 18 & 12 & 17.8 & 24.8 & 16.5 & n.d. & 7.7 & n.d. & n.d. \\
\hline $\mathbf{G a}$ & 17.5 & 14.9 & 15.6 & n.d. & 18.2 & n.d. & 22.6 & 10 & 10 \\
\hline $\mathbf{N i}$ & 94 & 126 & 101 & 159 & 41.4 & n.d. & 57 & 86 & 70 \\
\hline $\mathbf{V}$ & 209 & 180 & 212 & 217 & 202 & n.d. & 110 & 163 & 136 \\
\hline $\mathrm{Cr}$ & 567 & 821 & 643 & 793 & n.d. & n.d. & 350 & 209 & 191 \\
\hline Hf & 10.9 & 9.3 & 12.3 & n.d. & 9.7 & n.d. & 7.2 & 8 & 8 \\
\hline Ta & 0.8 & 0.8 & 1 & n.d. & 1.8 & n.d. & 1.1 & n.d. & n.d. \\
\hline La & 214.30 & 334.70 & 387.60 & n.d. & 243.80 & n.d. & 70.20 & 193.60 & 191.20 \\
\hline $\mathrm{Ce}$ & 554.30 & 667.90 & 821.10 & n.d. & 521.70 & n.d. & 147.20 & 405 & 424.30 \\
\hline Pr & 48.56 & 69.76 & 82.39 & n.d. & 61.37 & n.d. & 17.37 & n.d. & n.d. \\
\hline Nd & 186.80 & 268 & 311.70 & n.d. & 246.20 & n.d. & 71.90 & 185.50 & 237.10 \\
\hline Sm & 32.80 & 42.20 & 48.10 & n.d. & 36.90 & n.d. & 13.50 & 36.60 & 37.80 \\
\hline $\mathbf{E u}$ & 7.91 & 9.41 & 10.84 & n.d. & 8.57 & n.d. & 3.12 & 6.70 & 6.50 \\
\hline Gd & 19.64 & 24.53 & 27.36 & n.d. & 22.71 & n.d. & 9.62 & 21.90 & 18.40 \\
\hline $\mathbf{T b}$ & 2.27 & 2.75 & 3.09 & n.d. & 2.82 & n.d. & 1.23 & n.d. & n.d. \\
\hline Dy & 9.58 & 11.62 & 12.33 & n.d. & 11.51 & n.d. & 5.37 & 10.80 & 8.30 \\
\hline Ho & 1.42 & 1.72 & 1.89 & n.d. & 1.45 & n.d. & 0.99 & 1.90 & 1.40 \\
\hline $\mathbf{E r}$ & 3.56 & 3.66 & 4.21 & n.d. & 3.85 & n.d. & 2.63 & 3.70 & 2.50 \\
\hline $\mathbf{T m}$ & 0.46 & 0.53 & 0.55 & n.d. & 0.51 & n.d. & 0.38 & n.d. & n.d. \\
\hline $\mathbf{Y b}$ & 2.45 & 2.91 & 2.97 & n.d. & 3.00 & n.d. & 2.45 & 1.80 & 1.10 \\
\hline Lu & 0.42 & 0.41 & 0.44 & n.d. & 0.41 & n.d. & 0.35 & 0.15 & 0.12 \\
\hline
\end{tabular}


$3 \mathrm{wt} \%$ are in disagreement with the ultrapotassic series as proposed by Foley et al. (1987). However, Gameleira lamprophyres have most chemical characteristics similar to the shoshonitic rocks in the sense of Morrison (1980). According to the criteria of Morrison (1980) and Nardi (1986), the host monzonites (Table V) have also chemical affinity with the shoshonitic series, as deduced of its alkaline (Figure 9) and metaluminous character, moderate $\mathrm{Al}_{2} \mathrm{O}_{3}(15 \mathrm{wt} \%)$ and $\mathrm{P}_{2} \mathrm{O}_{5}(<0.6 \mathrm{wt} \%)$, low $\mathrm{TiO}_{2}(0.7 \mathrm{wt} \%)$ and high $\mathrm{Rb}, \mathrm{Sr}$ and $\mathrm{Ba}$. The classification diagram involving trace elements developed by Muller et al. (1992) also confirms that Gameleira lamprophyres are compositionally close to typical shoshonitic rocks (Figure 10).

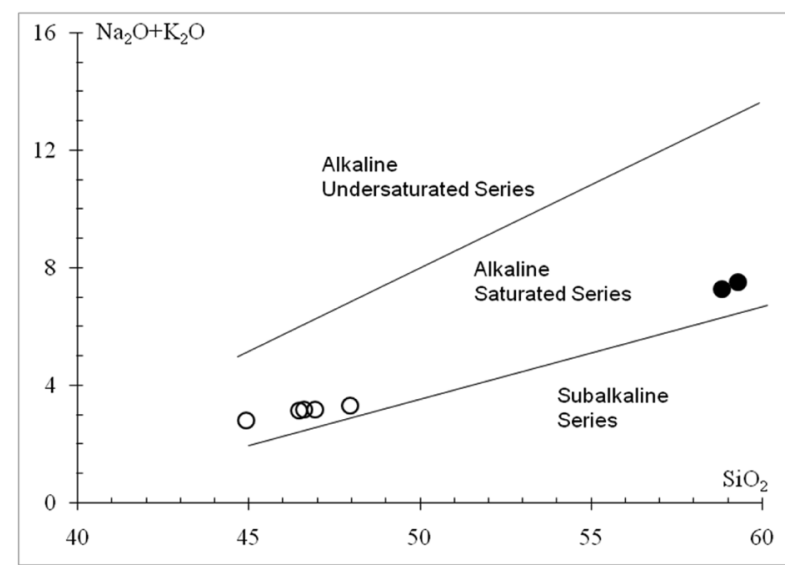

Figure 9. Chemical classification of plutonic rocks using the total alkalis $(\mathrm{Na} 2 \mathrm{O}+\mathrm{K} 2 \mathrm{O})$ vs $\mathrm{SiO} 2$ (TAS) diagram with the fields for alkaline and subalkaline rocks as deduced by Middlemost (1994). Open circles correspond to Gameleira lamprophyres and filled circles to host granites.

The very high contents of $\mathrm{MgO}$, above 10.9 $\mathrm{wt} \%$, as well as the very low $\mathrm{SiO}_{2}$ concentrations, point out to the primary composition of Gameleira lamprophyres. These rocks are also characterized by high $\mathrm{P}_{2} \mathrm{O}_{5}$ values $(1.4 \mathrm{wt} \%-2 \mathrm{wt} \%)$, whereas $\mathrm{TiO}_{2}$ shows moderate values $(1 \mathrm{wt} \%-1.5 \mathrm{wt} \%)$. $\mathrm{FeO}_{\mathrm{T}}, \mathrm{CaO}$ and $\mathrm{P}_{2} \mathrm{O}_{5}$ show a compatible behavior with $\mathrm{SiO}_{2}$, whereas $\mathrm{K}_{2} \mathrm{O}$ and $\mathrm{K}_{2} \mathrm{O} / \mathrm{Na}_{2} \mathrm{O}$ ratios increase with differentiation, suggesting that fractional crystallization was dominated by apatite

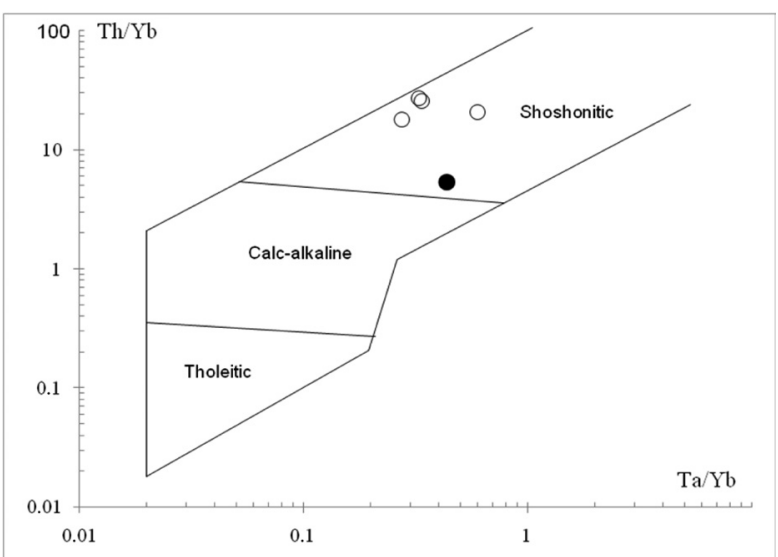

Figure 10. Discriminatory diagram among shoshonitic, tholeitic and calc-alkaline series using trace and rare earth elements, proposed by Muller et al. 1992. Gameleira rocks are into the shoshonitic compositional field.

and clinopyroxene. The incompatibility of $\mathrm{K}$ points to a minor participation of mica in the fractionation processes, and may suggest that lamprophyres and the monzonitic host are not genetically related.

The primary character of lamprophyre magmas is also recognized by the trace element contents. High concentrations of $\mathrm{Cr}(>500 \mathrm{ppm})$ and moderate to low of $\mathrm{Ni}(41-159 \mathrm{ppm})$ are in agreement with a mantle with high proportions of pyroxene and olivine-free. Gameleira lamprophyres are also enriched in $\mathrm{Ba}$ and $\mathrm{Sr}$, and show moderate contents of $\mathrm{Rb}$ (Table $\mathrm{V}$ ). The high concentrations of High Field Strengths Elements (HFSE), commonly observed in alkaline rocks of within-plate settings, are not observed in Gameleira lamprophyres that show moderate concentrations of $\mathrm{Y}$ and $\mathrm{Zr}$, and low $\mathrm{Hf}, \mathrm{Nb}$ and $\mathrm{Ta}$. Low contents of HFSE in potassic and ultrapotassic magmatism have been associated with a metasomatic mantle-source at subduction-related settings (e.g. Peccerillo 1985, Foley and Peccerillo 1992).

$(\mathrm{Ce} / \mathrm{Yb}) \mathrm{N}$ chondritic ratios, normalized by Evensen et al. (1980) values, are between 45 and 71, pointing to the strong enrichment of LREE and extremely fractionated REE-patterns (Figure 11). Such highly fractionated patterns are a consequence of the extreme enrichment of LREE, with Ce rea- 
ching up to $821 \mathrm{ppm}$ (Table V). Similar high amounts of LREE are observed in typical ultrapotassic rocks from within-plate (i.e. lamproites) and in lamprophyre magmas of post-collisional settings (i.e. minettes) (Foley 1992, Gibson et al. 1992), and are, therefore, correlated with the metasomatic process at the source and not necessarily with the tectonic setting. Eu-negative anomalies are not present in Gameleira Lamprophyres. REE-patterns from Morro do Afonso lamprophyres, which show a strong similarity with the Gameleira rocks, were plotted for comparison in Figure 11.

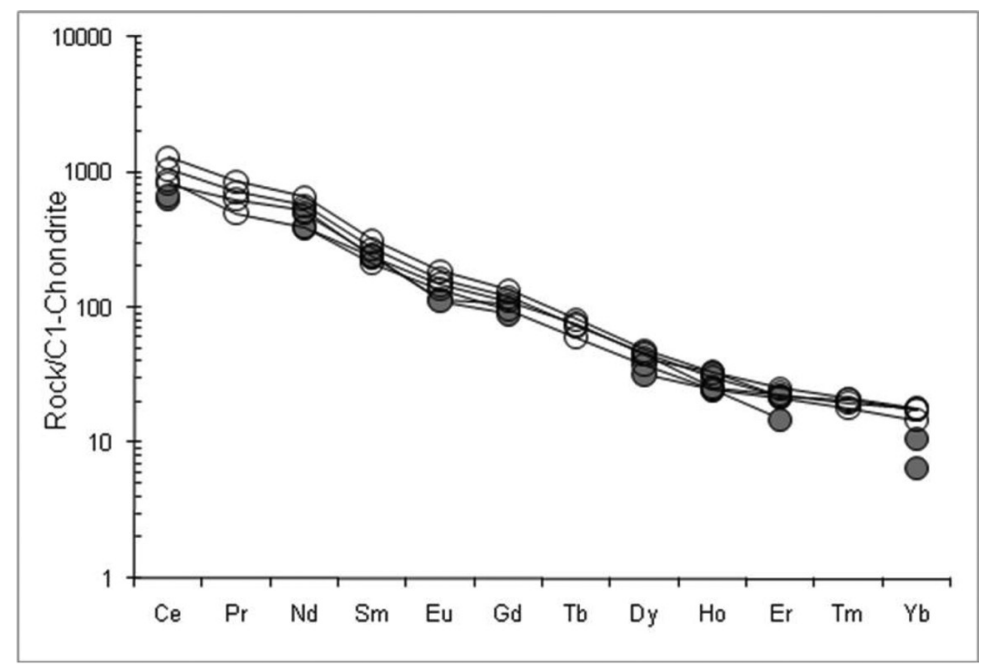

Figure 11. Rare Earth Elements normalized by C1-chondrite (Evensen et al. 1980) for Gameleira (open circles) and Morro do Afonso (shadow circles) lamprophyres.

Spidergrams of Gameleira and Morro do Afonso lamprophyres normalized to the primitive mantle values (McDonough and Sun 1995) are displayed in Figure 12, which shows the strong concentrations of LILE, except $\mathrm{Rb}$, and, as previously observed in Figure 11, the fractionation of HREE relative to LREE. Strong depletions are observed in $\mathrm{Nb}$ and $\mathrm{Ta}$, and a moderate one for Sr. Similar signatures have commonly been associated to subduction-related settings, and in this case with intense metasomatic processes associated to the mantle-source. The geochemical patterns of trace- and rare-earth elements of Gameleira and Morro do Afonso lamprophyres are quite similar, indicating similar sources for both alkaline Paleoproterozoic magmatisms.
Petrogenesis And Concluding Remarks

\section{Mineralogy}

The crystallization history of Paleoproterozoic lamprophyres in NE Brazil, associated to the syenitic intrusions from Cara Suja and Morro do Afonso (Rios 1997, Paim et al. 2002, Plá Cid et al. 2006), as well as, the minettes from Piquiri Syenite Massif (Plá Cid et al. 2002, 2003) in south Brazil, have shown similar near-liquidus paragenesis. Clinopyroxene-apatite-mica are the main mineral fractionated phases. However, in Piquiri and Cara Suja lamprophyres, a pargasitic amphibole was also identified as an early magmatic phase, as reported from inclusions in clinopyroxenes (Paim et al. 2002, 


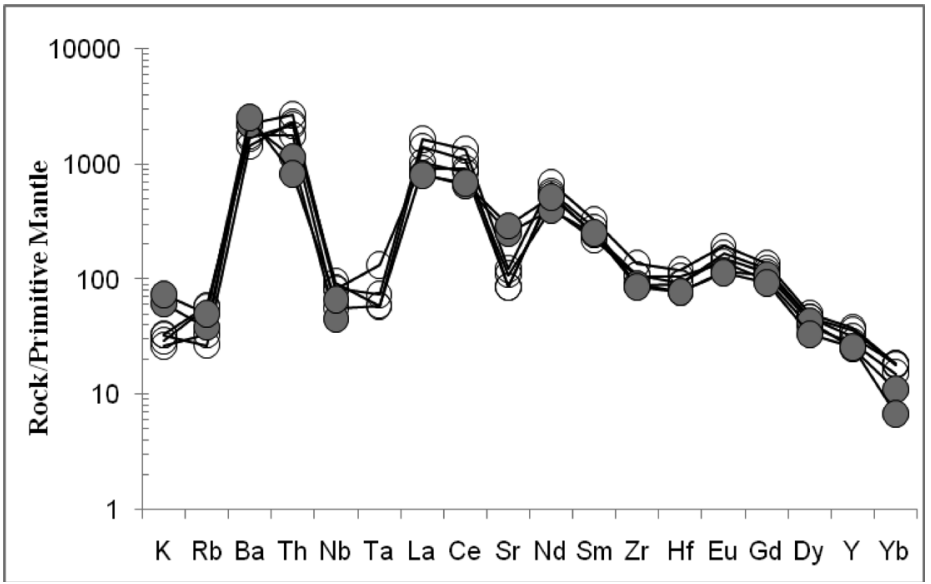

Figure 12. Primitive mantle- normalized spiderdiagram (Mc Donough and Sun 1995) for Gameleira (open circles) and Morro do Afonso (shadow circles) lamprophyres.

Plá Cid et al. 2003, Nardi et al. 2007). Although such inclusions in clinopyroxenes were not observed in Gameleira lamprophyres, cores of pargasitic composition in some amphibole grains may suggest that the near-liquidus mineralogy is similar to that found in potassic/ultrapotassic lamprophyres.

MacKenzie and Zusmann (1972) demonstrated that reverse zoning in feldspars was induced in supercooled magmas that suffered elevated mineral growth rate, and, in such conditions, some elements follow an 'effective distribution coefficient', rather than the equilibrium distribution coefficient. Such effective distribution coefficient induced in the melt/magma gradients of some elements only in the interface of crystallizing minerals/magma cause the disequilibrium between feldspars and liquid. In Gameleira lamprophyres, the high growth rate of the amphibole was induced by the emplacement of lamprophyric magma into narrow fractures in the host shoshonitic monzonite, establishing, in this way, a strong temperature gradient. At the moment of the emplacement, the lamprophyric magma was in the initial crystallization stage, with diopside, apatite, mica, and, probably, pargasite crystals. A considerable temperature contrast between the hotter lamprophyric magma and the host monzonite promoted, in a water-buffered system, the high rate of amphibole crystallization. Such "undercooling" induced in the lamprophyre magma a substantial growth rate of amphibole crystals, inducing a gradient of elements as $\mathrm{Ca}$, $\mathrm{Na}$ and $\mathrm{K}$ similar to that defined by MacKenzie and Zusmann (1972). As described previously, some feldspar grains were found as inclusions in amphibole phenocrysts close to the borders. This shows that syncrystallization between amphibole and feldspar occurred during the disequilibrium caused by high growth rates of the amphibole.

The crystallization of plagioclase and alkali feldspar occurred at the same time, and evidences of resorption were not observed. As pointed out by Nekvasil (1990), the re-sorption field in the AbAn-Or system contract with the increase of water and silica in the magma. The water-saturation of Gameleira lamprophyric magmas is corroborated by the large crystallization of mineral phases such as amphibole and apatite and, in minor scale, mica, since the earlier magmatic stages. As previously described, plagioclase and alkali feldspar crystallized together with later amphibole and apatite, showing that the crystallization of Gameleira lamprophyric magmas started under 
water-saturated conditions. $\mathrm{Ba}$ and $\mathrm{Sr}$ distribution in Gameleira lamprophyres is controlled by alkali feldspar and plagioclase crystallization, and the incompatibility of these elements was pointed out. Ba partition coefficient for plagioclase varies from 10 to 17 , whereas for alkali feldspar this value is below the unity. Sr distribution is preferentially controlled by plagioclase, with values between 6.6 and 9.5, against 2 to 6.6 for alkali feldspar. According to Rock (1991), feldspar of lamprophyres is normally enriched in $\mathrm{Ba}$ and $\mathrm{Sr}$. The crystallization order of Gameleira lamprophyres shows that the fractionation of the near liquidus mineral phases plus some pargasitic amphibole would produce monzonitic derived magmas enriched in $\mathrm{Ba}$ and $\mathrm{Sr}$.

Low modal percentage of titanium-bearing phases restricted to some late-magmatic titanite and Fe-Ti oxides is a consequence of the Ti-poor original composition of the magma. In Cara Suja (Paim et al. 2002) and Morro do Afonso lamprophyres (Plá Cid et al. 2006) the same characteristic was described, as well as in the Piquiri lamprophyres (Plá Cid et al. 2003).

The pressure dependence of ${ }^{\mathrm{IV}} \mathrm{Al}$ in the amphibole is suggested for these lamprophyres, by decreasing of 2.16 apfu (pargasite) to $1.32 \mathrm{apfu}$ (more evolved edenite), although, its use as a geobarometer is hardly admitted, since the paragenesis and rock chemistry are different from those used in the proposition of Hollister et al. (1987) and Schmidt (1992). Such chemical evolution of the amphibole is also controlled by increasing $\mathrm{fO}_{2}$-conditions. This is corroborated by the increase in the $\mathrm{Mg} /(\mathrm{Mg}+\mathrm{Fe})$ ratio due to coupled substitution $\mathrm{Mg}-\mathrm{Fe}^{+3}$ (Figure 13), and crystallization in the later magmatic stages of iron oxides. A similar behavior has been observed in other alkaline lamprophyres in NE Brazil (i.e. Cara Suja and Morro do Afonso lamprophyres) and spessartites from Volcanic Association of Lavras do Sul, Brazil (Lima and Nardi 1998).

A two-feldspar equilibrium geothermometer was developed by Stormer (1975). Using the

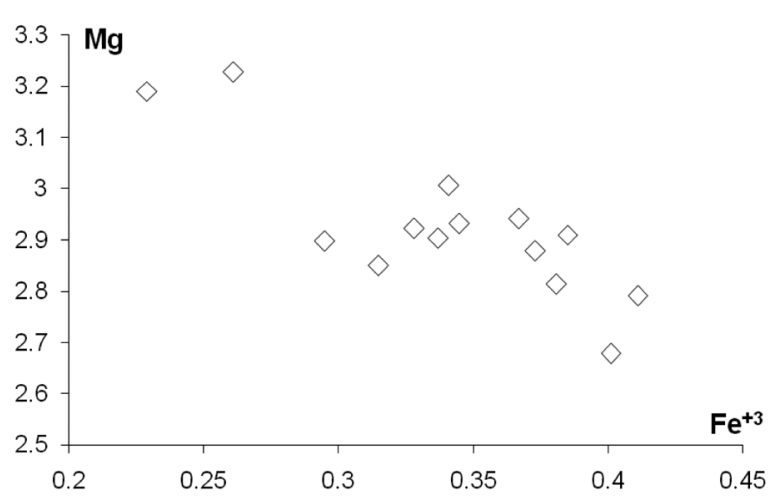

Figure 13. $\mathrm{Mg}$ (in apfu) vs. $\mathrm{Fe}^{+3}$ (in apfu) diagram of chemical evolution of Gameleira amphiboles.

curves proposed by this author, between 5 and $10 \mathrm{~kb}$, and compositions of alkali feldspar and plagioclase rims in contact with each other, nearsolidus temperatures were determined for these lamprophyres as close to $600^{\circ} \mathrm{C}$. The liquidus temperature of Gameleira lamprophyre magma can be estimated using the experimental determinations of Esperança and Holloway (1987) for minette lamprophyres. These authors found olivine-free near-liquidus paragenesis, dominated by diopside and phlogopite, as now reported in the Gameleira lamprophyres, in systems with temperatures around $1070^{\circ} \mathrm{C}$ and pressures of $10 \mathrm{~kb}$. Taking into account the similarity between magma compositions and liquidus mineralogy, such temperatures and pressures may be assumed to the Gameleira lamprophyre magma. Then, a range around $450^{\circ} \mathrm{C}$ can be estimated between liquidus and solidus temperatures of Gameleira lamprophyres, and a similar temperature contrast existed between lamprophyric magma and the host monzonite at the time of the intrusive event.

\section{Whole Rock Geochemistry}

Morro do Afonso lamprophyres have lower concentrations of $\mathrm{MgO}$ (6.8 to 7.7wt.\%) and $\mathrm{P}_{2} \mathrm{O}_{5}$ 
(1.5wt.\%), and higher $\mathrm{K}_{2} \mathrm{O}$ (4.1 to $\left.4.9 \mathrm{wt} . \%\right), \mathrm{Al}_{2} \mathrm{O}_{3}$ (10.6 to 11.2 wt.\%), and $\mathrm{K}_{2} \mathrm{O} / \mathrm{Na}_{2} \mathrm{O}$ ratios $(3-4)$ relative to Gameleira lamprophyres (Table V). According to several authors (Loyd et al. 1985, Foley 1992, Foley and Peccerillo 1992, Ionov et al. 1997, and references therein), pyroxene, apatite, phlogopite and amphibole are the usual phases found in the upper mantle metasomatized zones. As emphasized by Foley (1992), different proportions of these minerals and, to a lesser extent, of typical mantle phases (garnet, olivine, spinel) participating in the melting processes may explain the diversity of alkaline potassium-enriched magmas. The comparison between Gameleira and Morro do Afonso primary magmas puts in evidence the presence of higher proportions of potassium-rich phases in the source of these lamprophyres. The main carriers of potassium in the upper mantle are phlogopite and amphiboles (pargasite and richterite), and mica seems to be dominant in the metasomatic source of Morro do Afonso magmas, whereas relatively lower amounts of potassium in Gameleira lamprophyres may be related to higher proportions of amphibole at the source. This is also supported by the lower $\mathrm{Al}_{2} \mathrm{O}_{3}$ values in Gameleira lamprophyres, suggesting lower amounts of phlogopite at the source. Apatite is an abundant phase in both sources, as attested by high $\mathrm{P}_{2} \mathrm{O}_{5}$ in both lamprophyres; and, clinopyroxene is dominant in the source of Gameleira, as deduced from its higher $\mathrm{MgO}$ content. Experimental data of Conceição and Green (2000) have shown the importance of phlogopite and pargasite melting in the upper-mantle, for the production of potassic liquids. Different melting rates of the same source could be an alternative hypothesis to explain some geochemical differences between Gameleira and Morro do Afonso lamprophyres.

The $\mathrm{Cr}$ concentrations of Gameleira lamprophyre, compared to Morro do Afonso rocks, confirm the supposition of higher proportions of clinopyroxene at its source. Low to moderate $\mathrm{Ni}$ concentrations in both indicates an olivine-free source. Ba contents are similar in both associations, and are probably concentrated by different K-rich phases (mica and amphibole) at the source of both primary magmas. O'Reilly and Griffin (2000) suggested that apatite is the main carrier of LREE in the mantle. Slightly higher contents of $\mathrm{P}_{2} \mathrm{O}_{5}$ in Gameleira magmas (Table V) are in agreement with the higher concentrations of elements such as $\mathrm{La}, \mathrm{Ce}$ and Nd when compared to Morro do Afonso lamprophyres (Table V; Figure 11). Considering the concentrations of compatible elements in Morro do Afonso and Gameleira lamprophyres, a higher melting rate would be expected for the source of Gameleira magma. This can explain the lower amounts of $\mathrm{K}$ and $\mathrm{Al}$ in Gameleira rocks, but not the concentrations of LREE and P, higher in these rocks than in the ultrapotassic Morro do Afonso lamprophyres. In this way, slight mineralogical differences at the source and different melting rates can explain the differences in geochemical patterns of both lamprophyre magmas.

Gameleira lamprophyres represent potassic liquids, with a geochemical signature typically related to a mantle-source affected by metasomatic process related to dehydration and/or melting of subductedslab. Very high concentrations of $\mathrm{MgO}, \mathrm{P}_{2} \mathrm{O}_{5}, \mathrm{Cr}$, $\mathrm{Ba}, \mathrm{Cs}$ and LREE are indicative of a mantle-source enriched in apatite and clinopyroxene, whereas the moderate amounts of $\mathrm{K}_{2} \mathrm{O}$ when compared with the contemporaneous ultrapotassic liquids from Morro do Afonso Massif suggest higher proportions of amphibole relative to mica. The water-saturated primary magmas of Gameleira lamprophyres is another evidence of the presence of amphibole and mica in the mantle source.

The comparison of both primary magmas from Gameleira and Morro do Afonso lamprophyre associations forming bodies separated just by a few kilometers on the field and, probably contemporaneous, is a strong argument for mantle heterogeneity as the main cause of different types 
of alkaline liquids. The identification of different mineral paragenesis in the source of ultrapotassic and potassic lamprophyres from São Francisco Craton constitutes a useful approach for understanding the mantle and crustal evolution in northeastern Brazil.

\section{ACKNOWLEDGMENTS}

The authors thank to Drs. Excelso Ruperti and Silvio Roberto Farias Vlach, and Marcos Mansueto, from São Paulo University, by the acquisition of electron microprobe data in all minerals.

\section{RESUMO}

Os lamprófiros Gameleira são formados por diques e enclaves máficos microgranulares associados ao monzonito shoshonítico Gameleira. Esta associação pertence ao magmatismo alcalino Paleoproterozóico do núcleo Serrinha, nordeste do Brasil. A paragênese no liquidus é formada por diopsídio, pargasita, apatite e mica. Zonamento inverso foi identificado no feldspato alcalino da matriz e relacionado ao super-resfriamento do magma lamprofírico durante sua colocação, com alta taxa de crescimento da pargasita/edenita induzindo desequilíbrio entre os feldspatos e o líquido. Dados químicos indicam que os lamprófiros são rochas básicas $\left(\mathrm{SiO}_{2}<48 \%\right)$, com caráter alcalino $\left(\mathrm{Na}_{2} \mathrm{O}+\mathrm{K}_{2} \mathrm{O}>3 \%\right)$ e assinatura potássica $\left(\mathrm{K}_{2} \mathrm{O} / \mathrm{Na}_{2} \mathrm{O} \approx 2\right)$. Elevados conteúdos de $\mathrm{MgO}$ e $\mathrm{Cr}$ são consistentes com uma assinatura primária, e tais concentrações, assim como os conteúdos de Al, $\mathrm{K}, \mathrm{P}, \mathrm{Ba}, \mathrm{Ni}$, e terras raras leves são consistentes com uma fonte mantélica metassomatizada sem olivine, enriquecida em anfibólio, clinopiroxênio e apatita. Por outro lado, os lamprófiros ultrapotássicos de Morro do Afonso, magmatismo alcalino contemporâneo no núcleo Serrinha, foram produzidos por uma fonte enriquecida em clinopiroxênio, flogopita e apatita. A identificação de diferentes paragênesis minerais na fonte de lamprófiros potássicos e ultrapotássicos do núcleo Serrinha pode contribuir para a compreensão das heterogeneidades do manto e a evolução tectônica desta região.
Palavras-chave: lamprófiros potássicos, lamprófiros Gameleira, Cráton do São Francisco, metassomatismo mantélico, petrologia, mineralogia.

\section{REFERENCES}

BONIN B. 1996. A-type granite ring complexes: mantle origin through crustal filters and the anorthosite-rapakivi magmatism connection. In: PETROLOGY AND GEOCHEMISTRY OF MAGMATIC SUITES OF ROCKS IN THE CONTINENTAL AND OCEANIC CRUSTS, ULB-MRAC, Bruxelles, p. 201-217.

BONIN B AND GIRET A. 1985. Clinopyroxene compositional trends in oversaturated and undersaturated alkaline ring complexes. J Afr Earth Sci 3: 175-183.

CONCEIÇÃO RV AND GREEN T. 2000. Derivation of potassic (shoshonitic) magmas by decompression melting of phlogopite + pargasite lherzolite. Lithos 72: 209-229.

CORRIVEAU L AND GORTON MP. 1993. Coexisting K-rich alkaline and shoshonitic magmatism of arc affinities in the proterozoic - a reassessment of syenitic stocks in the southwestern Grenville Province. Contrib Mineral Petrol 113: 262-279.

ESPERANÇA S AND HOLLOWAY JR. 1987. On the origin of some micalamprophyres: experimental evidence from a mafic minette. Contrib Mineral Petrol 95: 207-216.

EVENSEN NM, HAMILTON PJ AND O'NiONS RK. 1980. Rare earth abundance in chondritic meteorites. Geoch Cosmoch Acta 42: 1199-1212.

FOLEY S. 1992. Petrological characterization of the source components of potassic magmas: Geochemical and experimental constraints. Lithos 28: 187-204.

Foley S AND PeCCERILlo A. 1992. Potassic and ultrapotassic magmas and their origin. Lithos 28: 181-185.

Foley S, Venturelli G, GREEN DH AND TOSCANI L. 1987. The ultrapotassic rocks: Characteristics, Classification, and Constraints for petrogenetic models. Earth-Sci Rev 24: 81-134.

GIBSON AS, THOMPSON RN, LEAT PT, MORRISON MA, HENDRY GL, DiCKIN AP AND MitChELl JG. 1992. Ultrapotassic magmas along the flanks of the Oligo-Miocene Rio Grande Rift, USA: Monitors of the zone of lithospheric mantle extension and thinning beneath a continental rift. J Petrol 34: 87-228.

Hollister LS, Grisson GC, Peters EK, Stowell HH AND SISSON VB. 1987. Confirmation of the empirical correlation of $\mathrm{Al}$ in hornblende with pressure of solidification of calcalkaline plutons. Am Mineral 72: 231-239.

IONOV DA, GRIFFIN WL AND O'REILLY SY. 1997. Volatilebearing minerals and lithophile trace elements in the upper mantle. Chem Geol 141: 153-184.

LAMEYRE J AND BOWDEN P. 1982. Plutonic rock types series discrimination of various granitoid series and related rocks. J Volc Geoth Res 14: 169-186. 
LE MAITRE RW ET AL. 1989. A Classification of Igneous Rocks and Glossary of Terms: Recommendations of the International Union of Geological Sciences Subcommission on the Systematics of Igneous Rocks, Blackwell, Oxford, London, $193 \mathrm{p}$.

LEAKE BE ET AL. 1997. Nomenclature of amphiboles: Report of the subcommittee on Amphiboles of the International Mineralogical Association, Commission on New Minerals and Mineral Names. Am Mineral 82: 1019-1037.

LEAT PT, THOMPSON RN, MORRISON MA, HENDRY GL AND DICKIN AP. 1988. Silicic magmas derived by fractional crystallization from miocene minette, Elkhead mountains, Colorado. Min Mag 52: 577-585.

LIMA EF AND NARDI LVS. 1998. Química mineral das rochas vulcânicas e lamprófiros espessartíticos da Associação Shoshonítica de Lavras do Sul-RS. Rev Brasil Geoc 28: 113-124.

LOYd FE, ARIMA M AND EdGAR AD. 1985. Partial melting of a phlogopite cliopyroxenite nodule from south-west Uganda: an experimental study bearing on the origin of highly potassic continental rift volcanics. Contrib Mineral Petrol 91: 321-329.

MaCKEnZIE WS AND ZuSMAnN J. 1972. The Feldspars. Manchester University Press, Manchester, 459 p.

Mascarenhas JF. 1979. Evolução geotectônica do PréCambriano do Estado da Bahia. Geologia e Recursos Minerais do Estado da Bahia. In: TEXTOS BÁSICOS EM GEOLOGIA, Secretaria de Minas e Energia, Salvador, p. 57-165.

MCDONOUGH WF AND Sun S-S. 1995. The composition of the Earth. Chem Geol 120: 223-253.

Middemost EAK. 1994. Naming materials in the magma/ igneous rock system. Earth-Sci Rev 37: 215-224.

Morimoto CN. 1988. Nomenclature of pyroxenes. Am Mineral 73: 1123-1133.

MORRISON GW. 1980. Characteristics and tectonic settings of the shoshonite rock association. Lithos 13: 97-108.

Muller D, RocK NMS AND GROVES DI. 1992. Geochemical discrimination between shoshonitic and potassic volcanic rocks in different tectonic settings. A pilot study. Mineral Petrol 46: 259-289.

NARDI LVS. 1986. As rochas granitóides da série shoshonítica. Rev Brasil Geoc 16: 3-10.

NARDI LVS AND BONIN B. 1991. Post orogenic and non orogenic alkaline granite associations: the Saibro Intrusive Suite, Southern Brasil. A case study. Chem Geol 92: 197-212.

NARdi LVS, PlÁ Cid J ANd Bitencourt MF. 2007. Minette mafic microgranular enclaves and their relationship to host syenites in systems formed at matle pressures: major and trace element evidence from the Piquiri Syenite Massif, southernmost Brazil. Mineral and Petrol 91: 101-116.

NeKVAsil H. 1990. Reation relations in the granite system: Implications for traquitic and syenitic magmas. Am Mineral 75: 560-571.

NEUMANN ER. 1976. Compositional relations among pyroxenes, amphiboles and other mafic phases in the Oslo region plutonic rocks. Lithos 9: 85-109.
O'REILLY SY AND GRIFFIN WL. 2000. Apatite in the mantle: implications for metasomatic processes and high heat production in Phanerozoic mantle. Lithos 53: 217-232.

PAIM MM, PlÁ CID J, Rosa MLS, CONCEIÇão H AND NARDI LVS. 2002. Mineralogy of Lamprophyres and Mafic Enclaves Associated with the Paleoproterozoic Cara Suja Syenite, Northeast Brazil. Int Geol Rev 44: 1017-1036.

PECCERILlO A. 1985. Roman comagmatic province (central Italy): evidence for subduction-related magmas. Earth Planet Sci Lett 95: 53-72.

Plá Cid J, Cruz Filho BE, Conceição H, Rios DC, Rosa MLS AND ROCHA HM. 2007. Primary potassic magmatism produced from amphibole-clinopyroxeneapatite-rich mantle source in the São Francisco Craton, Brazil, and the key role of mantle heterogeneity in the diversity of alkaline magmatism. Rev Bras Geoc 37: 40-46.

Plá Cid J, NARdi LVS, CONCEIÇÃo H ANd Bonin B. 2001. Anorogenic alkaline granites from northeastern Brazil: major, trace, and rare earth elements in magmatic and metamorphic biotite and Na-mafic minerals. J Asian Earth-Sci 19: 375-397.

Plá Cid J, NARdi LVS, Conceição RV, Stabel LZ AND BALZARETTI NM. 2003. K- clinopyroxene, pyrope-rich garnet, and potassian pargasite from mafic microgranular enclaves of Piquirı Syenite, southernmost Brazil: evidences of syenitic and minettic magma mingling at upper mantle pressures. Contrib Mineral Petrol 145: 444-459.

PLÁ CID J, NARDi LVS AND ENRIQUE P. 2002. Textural relations of lamprophyric mafic microgranular enclaves and petrological implications for the genesis of potassic syenitic magmas: the example of Piquiri Syenite, southern Brazil. Pesq Geoc 29: 21-30.

Plá Cid J, Rios DC AND CONCEIÇÃo H. 2006. Petrogenesis of mica-amphibole-bearing lamprophyres associated with the Paleoproterozoic Morro do Afonso syenite intrusion, eastern Brazil. J. South Am Earth-Sci 22: 98-115.

RINGWOOD AE. 1990. Slab-mantle interactions. 3. Petrogenesis of intraplate magmas and structure of the upper mantle. Chem Geol 82: 187-207.

Rios DC. 1997. Petrologia do magmatismo potássico-ultrapotássico e lamprofírico de Morro do Afonso-Bahia (Petrology of the Morro do Afonso potassic-ultrapotassic and lamprophyric magmatism). MSc Thesis. Universidade Federal da Bahia, Salvador, Brasil 237 p. (Unpublished).

RIOS DC. 2002. Granitogênese no núcleo Serrinha, Bahia, Brasil: Geocronologia e Liteogeoquímica (Granitogenesis in the Serrinha nucleus, Bahia, Brazil: Geochronology and Geochemistry). PhD Thesis, CPGG-UFBA, Salvador, 239 p.

RocK NMS. 1987. The nature and origin of lamprophyres: an overview. In: ALKALINE IGNEOUS ROCKS, London 30: 191-226.

RoCK NMS. 1991. Lamprohyres. Blackie, Glasgow, 285 p.

RosA MLS, CONCEIÇÃo H, MARINHO MM, MACAMBIRA MJB AND MARQUES LS. 2002. Geochronology of the South Bahia Alkaline Province (NE Brazil). Geoch Cosmoch Acta 66: A648. 
ROSA MLS, MENEZES RCL, CONCEIÇÃO H, MACAMBIRA MJB, GALARZA MA, OLIVEIRA EC, MARINHO MM AND RIOS DC. 2005. Geochronology of a rare alkaline magmatism: the blue sodalite-syenite ore (NE Brazil). In: GOLDSCHMIDT CONFERENCE 2005. Geoch Cosmoch Acta, Amsterdam, A82. p.

SCHMIDT MW. 1992. Amphibole composition in tonalites as a function of pressure: an experimental calibration of the Al-inhornblende barometer. Contrib Mineral Petrol 110: 304-310.

Silva AB, LiBERAL GS, SAD JHG, ISSA FILHO A, Rodrigues CS AND RIFFEL BF. 1988. Geologia e petrologia do Complexo Angico dos Dias (Bahia, Brasil): uma associação carbonatítica pré-cambriana. Geochim Brasil 2: 81-108.
SOMMER CA, Lima EF, NARdi LVS, FigUEIREDO AMG AND PIEROSAN R. 2005. Potassic and low- and high- Ti mildly alkaline volcanism in the Neoproterozoic Ramada Plateau, southernmost Brazil. J South Am Earth Sci 18: 237-254.

STORMER JR JC. 1975. A practical two-feldspar geothermometer. Am Mineral 60: 667- 674.

THOMPSON RN AND FOWLER MB. 1986. Subduction-related shoshonitic and ultrapotassic magmatism - a study of siluro-ordovician syenites from the Scottish Caledonides. Contrib Mineral Petrol 94: 507-522.

Whalen JB, CURrie KL And Chappell BW. 1987. A-type granites - Geochemical characteristics, discrimination and petrogenesis. Contrib Mineral Petrol 95: 407-419. 